Article

\title{
High-Resolution Observations of Transport and Exchange Processes in Mountainous Terrain
}

\author{
Stefan Emeis ${ }^{1, *} \mathbb{\infty}$, Norbert Kalthoff ${ }^{2}$, Bianca Adler ${ }^{2} \mathbb{D}$, Eric Pardyjak ${ }^{3}$, Alexandre Paci ${ }^{4} \mathbb{C}$ and \\ Wolfgang Junkermann ${ }^{1}$ \\ 1 Karlsruhe Institute of Technology, Institute of Meteorology and Climate Research-Atmospheric \\ Environmental Research, 82467 Garmisch-Partenkirchen, Germany; wolfgang.junkermann@kit.edu \\ 2 Karlsruhe Institute of Technology, Institute of Meteorology and Climate Research-Tropospheric Research, \\ 76021 Karlsruhe, Germany; norbert.kalthoff@kit.edu (N.K.); bianca.adler@kit.edu (B.A.) \\ 3 Environmental Fluid Dynamics Lab, University of Utah, Salt Lake City, UT 84112, USA; \\ pardyjak@mech.utah.edu \\ 4 Centre National de Recherches Météorologiques (CNRM), METEO-FRANCE, CNRS (UMR 3589), \\ 31100 Toulouse, France; alexandre.paci@meteo.fr \\ * Correspondence: stefan.emeis@kit.edu
}

Received: 9 July 2018; Accepted: 12 November 2018; Published: 22 November 2018

\begin{abstract}
Mountainous areas require appropriate measurement strategies to cover the full spectrum of details concerning the energy exchange at the Earth's surface and to capture the spatiotemporal distribution of atmospheric dynamic and thermodynamic fields over them. This includes the range from turbulence to mesoscale processes and its interaction. The surface energy balance needs appropriate measurement strategies as well. In this paper, we present an overview of important experiments performed over mountainous terrain and summarize the available techniques for flow and energy measurements in complex terrain. The description includes ground-based and airborne in situ observations as well as ground-based and airborne remote sensing (passive and active) observations. Emphasis is placed on systems which retrieve spatiotemporal information on mesoscale and smaller scales, fitting mountainous terrain research needs. Finally, we conclude with a short list summarizing challenges and gaps one faces when dealing with measurements over complex terrain.
\end{abstract}

Keywords: measurements; mountainous terrain; complex terrain; remote sensing; in situ observations

\section{Introduction}

Mountainous areas contribute to the generation and modification of synoptic-scale and meso-scale atmospheric flows in various ways. For example, mountains deviate large-scale flows, excite orographic precipitation [1], and exerting gravity wave drag (see [2,3] for overviews). Both weather and climate modeling require a correct representation of these processes on all scales [4]. This correct representation has to take into account that mountains also significantly contribute to the modification of micrometeorological fluxes and energy budgets, because of the intimate interaction between boundary-layer structures and orographic features. Important international activities in the past (e.g., the Alpine Experiment (ALPEX) [5], the Pyrenees Experiment (PYREX) [6], the Southern Alps Experiment (SALPEX) [7], and the Mesoscale Alpine Programme (MAP) [8]) have addressed these issues. Especially the last one, MAP, has addressed atmospheric boundary layer issues in more detail [9]. Another important project, which included experiments related to transport and exchange over complex terrain, was TRACT (Transport and air pollutants over complex terrain, [10]). This latter project addressed the spectrum of processes which are relevant to describe the transport and turbulent 
diffusion in the lower atmosphere over complex terrain. Special emphasis was placed on the integration of field observations and mesoscale modeling. Since then, physical scales in time and space that can, in principle, be treated in observations and modeling have been getting continuously smaller [11]. Surface and airborne remote sensing as well as more satellite programs provide not only better spatial resolution but also better temporal and spatial coverage [12].

Specific mountainous processes which must be considered in more detail in future energy budget assessments and in climate and weather modeling should include:

- small- and meso-scale mountain induced flow patterns (slope winds, valley and mountain winds, and alpine pumping [13]); including their interaction

- triggering and development of convection; including associated venting of energy and substances from the atmospheric boundary layer into the free troposphere

- micrometeorological fluxes at elevated surfaces [14,15].

Horizontal homogeneity which has been the paramount assumption in so many boundary-layer exchange studies in the past decades (see, e.g., [16] or [17]) should no longer be considered appropriate. Neglecting horizontal gradients in the governing equations, which had led to marvelously simple equations and relations in boundary-layer meteorology, is not viable for future mountainous atmospheric research.

New mountain campaigns have to aim at investigating processes contributing to transport and exchange processes between mountainous terrain, the boundary layer, and the free atmosphere at all scales with emphasis on multi-scale interactions. These interactions between relatively well-known processes at meso-scale or synoptic scale and local scales must be much better established so as to assess the relative importance of the different processes in order to decide which of them need to be parameterized in numerical weather prediction and climate models. Moreover, the type of parameterizations should take into model resolution and specific modeling goals. The investigation of the 'small-scale end' (i.e., boundary-layer processes such as turbulent exchange, local flows, budgets, scaling approaches, and boundary-layer structures in complex topography) is just at its beginning.

The interaction of different scales in the atmosphere with various types of topographic features is not yet fully understood. This hampers even the identification of where to begin investigating the interactions from small-scale to larger-scale processes in complex terrain [18]. Some experimental and monitoring initiatives in recent years have already started to fill this gap. Among these are the American effort Mountain Terrain Atmospheric Modeling and Observations (MATERHORN) [19], the Catalan/Spanish and French effort Cerdanya-2017 [20,21], and the German ecosystem exchange program Terrestrial Environmental Observatories (TERENO), with four sites of which three are in complex terrain [22]. There had been even more detailed campaigns such as the Meteor Crater Experiment (METCRAX) in 2006 [23], METCRAX II in 2013 [24], and the Across Scales Experiment (ScaleX) at the alpine site of TERENO looking at very small scales in mountainous terrain [25]. The ScaleX experiment investigated the conditions for land-air exchange fluxes in a small valley north of the Alps using a large variety of both ground-based and airborne in situ and remote sensing instruments. The backbone of micrometeorological, hydrological and ecosystem-atmosphere exchange instrumentation used by ScaleX was formed by the permanent environmental TERENO-pre-Alpine observatory, with stations distributed along an elevation gradient in the pre-Alpine region. One of the driving research questions for this experiment is to understand why the surface energy balance has yet to be truly closed [26]. Further field campaigns over complex, mountainous terrain applying in-situ and remote sensing systems include: the Terrain-Induced Rotor Experiment (T-REX) in 2006 [27], the Convective and Orographically-induced Precipitation Study (COPS) in 2007 [28], the HYdrological cycle in the Mediterranean Experiment (HYMEX) in 2012 [29], and Passy-2015 (Passy is a city in the French Alps) [30,31]. Long-term measurements are performed in the Inn Valley in the Alps within the i-Box project to study turbulent exchange processes [32]. 
Moreover, climate simulations require taking into account significantly longer impact time scales (e.g., permanent and semi-permanent surface characteristics such as vegetation, snow, and ice) in local exchange processes than numerical weather prediction models. Parameterizing, for example, the surface water budget based on concepts adapted from those for flat terrain may not decisively 'deteriorate the weather forecast' (e.g., producing the wrong amount of rain in the wrong place and at the wrong time does not really harm the forecast for the next few hours), but it might systematically yield too much (or too little) evaporation. This could result in a particular location (not necessarily only the one concerned with the evaporation) becoming too dry (wet) over the years of simulation, thus altering the meso-scale flow patterns and feeding back to the large-scale flow. Also, application-oriented issues such as the siting of wind turbines (see, e.g., [33] or [34]), urban air quality (e.g., for Santiago de Chile [35]), and air quality in mountainous terrain (e.g., the Salt Lake Valley in the United States [36], the Arve valley [30,31] and the Adige valley [37] in the Alps, and in the framework of the project ALPNAP the Inn valley [38] and the Brenner cross-section in the Alps [39]) need more high-resolution observations [40].

Finally, large national meteorological and climate centers are moving from numerical weather prediction and/or climate scenario simulations to developing Earth-System Modeling capacities (see, e.g., [41]). Earth system models include atmospheric constituents such as aerosols and trace gases and deal with vegetation feedback. Therefore, these models must account for the details of earth-atmosphere exchange over mountainous as well-or more generally-complex terrain. These efforts have to be substantiated by respective observational data.

The purpose of this contribution to a series of further papers overviewing the knowledge and challenges on mountain meteorology $[1,11,14,15,18,42,43]$ is to address the necessary observational techniques which have to be made available in order to achieve the relevant information of transport and exchange processes in complex terrain. The focus will be on radiation, kinetic energy, heat and moisture. Exchange of atmospheric trace substances will not be addressed, although some knowledge on turbulent heat and humidity fluxes can be transferred for this purpose. Therefore, Section 2 will address the overall challenges, which influence observations in mountainous terrain. Section 3 will then address surface in situ and surface-based remote sensing observations. Section 4 describes challenges of airborne and space-borne observations. Conclusions and outlook will close this review.

\section{Overall Challenges to Observations in Orographically Complex Terrain}

Mountainous terrain influences static stability, dynamics, and thermodynamics of the atmosphere around and above it $[44,45]$. Strong horizontal inhomogeneity and considerable secondary diurnal circulations result in observations that are only representative of a very limited spatial and temporal extent [46]. Static stability of air in valleys and close to mountains is modified by limited horizontal exchange, by radiative fluxes from elevated terrain, and by secondary circulations, which modify or even suppress turbulent vertical exchange. For instance, calm wintry conditions with a surface snow cover can lead to vertical layering in valleys (see Figure 1 and [47]). The flow dynamics are modified by flow over mountains and ridges, flow around mountains and flows through gaps, channels, and passes. Colder air masses can be trapped behind barriers. An extreme example of such local flows is the Laseyer wind in northeastern Switzerland which is not yet fully understood but is able to derail trains [48]. The Laseyer-wind case study points to a need for very high horizontal resolution modeling in complex terrain (in this case better than $50 \mathrm{~m}$ ). Similarly, the Passy- 2015 case showed that a horizontal resolution of at least $100 \mathrm{~m}$ is needed [49].

Modified thermodynamics may lead to suppressed or enhanced cloud and precipitation formation by thermally or dynamically forced vertical motion. Such vertical exchange processes have been part of the focus of the larger European research project Vertical Ozone Transport in the Alps (VOTALP) [50]. Relevant secondary diurnal circulations are slope winds, valley winds, and meso-scale winds towards or away from larger mountain chains. Examples of measurements and model simulations are given in 
the literature for these type of winds in the Elqui valley in the Andes [51,52] and the Adige valley in the Alps [53].

All the above-mentioned studies demonstrated strong spatial variability of nearly all atmospheric variables, which limits the spatial and temporal representativeness of data obtained by measurements (especially those describing larger spatial and temporal scales). For small-scale and micrometeorological variables and turbulence characteristics such as displacement heights, roughness lengths, spectral peaks, turbulent length scales, and profiles of turbulent intensities, the local surface properties exert considerably more influence than topographical complexity does [54]. The representativeness of observations may be assessed by footprint models [55], however, parameterized footprint models (e.g., [56]) are only valid for homogeneous terrain. More sophisticated models (e.g., [57]) require considerable computational resources [58].

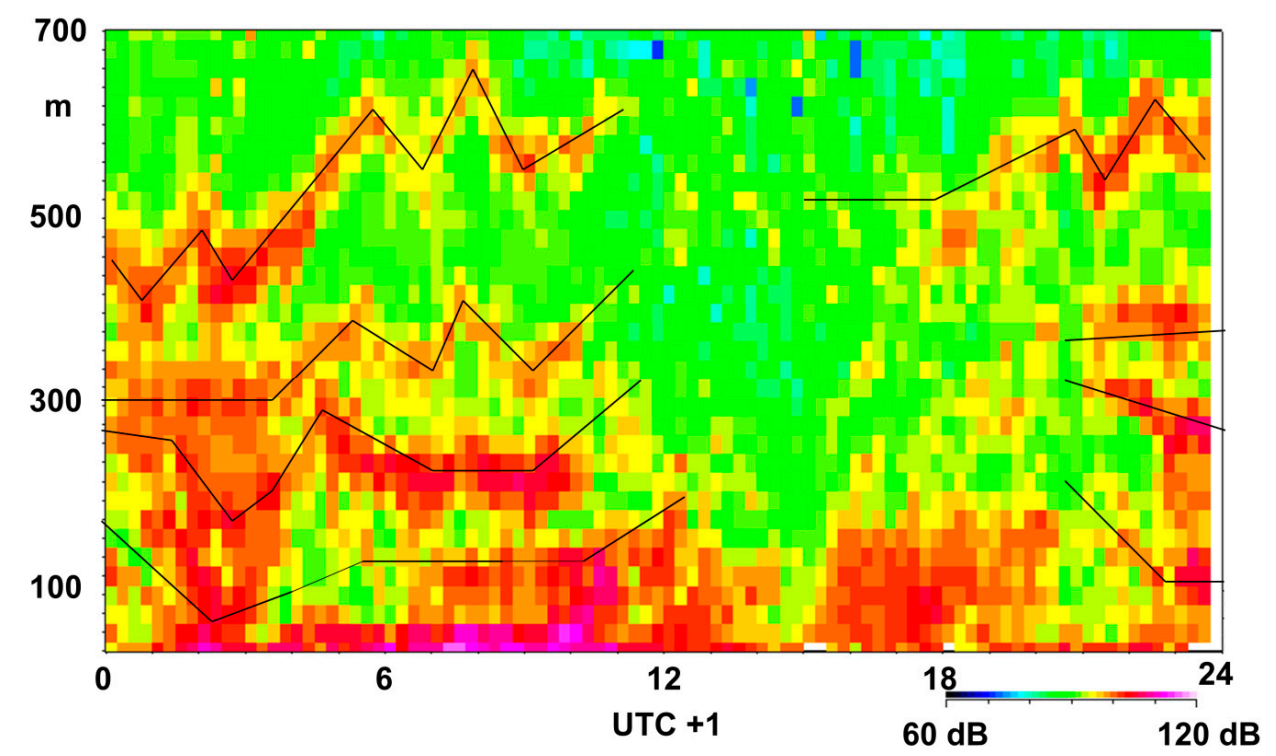

Figure 1. Multi-level layering in a calm wintry Alpine valley. Time-height cross-section of acoustic reflectivity (in dB) from a surface-based sodar in the Inn Valley east of Innsbruck on 29 January 2006. The image covers $24 \mathrm{~h}$ (UTC+1, from left to right) and a $660 \mathrm{~m}$ height interval from $40 \mathrm{~m}$ to $700 \mathrm{~m}$ above ground (from below to top). Green colors indicate lower reflectivity and red colors higher reflectivity. The thin black lines indicate borders between air layers within increasing potential temperature from lower to higher layers (adapted from [47]).

In contrast to flat, horizontally homogeneous terrain, the exchange and transport of moisture, heat, and mass are controlled not only by convection, but also by thermally induced mesoscale flows and synoptic scale flows [15]. Besides measuring the turbulent fluxes at the surface, it is thus essential to observe local flows and advection with the mean flow as well. Minimal required observations should include profile measurements of mean quantities such as moisture and temperature at several locations (e.g., in and above valleys, above slopes, and around ridges) along with good knowledge of the three-dimensional flow structure with an appropriate resolution. This poses challenges not only to the measurement techniques and instruments, but also to the coordination and infrastructure. Finding measurement sites in mountainous terrain is usually a compromise between the "best" site from a scientific point of view and feasibility (e.g., sites must be accessible, power supply has to be assured, and landowner permission is needed).

\section{Surface Measurement Techniques}

General guidelines and overviews on atmospheric measurement techniques at representative sites, which are usually located in flat or only gently rolling terrain, exist in excellent resources (e.g., [12,59]). But measurements to be conducted in mountainous terrain and other types of complex heterogeneous 
terrain (e.g., urban) face additional challenges related to spatial representativeness and the application of certain algorithms, which postulate horizontal homogeneity (e.g., [60]). Measurements need to monitor the state of the atmosphere and its variability in three dimensions and need to cover a large range of spatial and temporal scales. For example, measurements of the radiation and energy balance have to account for the impact of local slopes (e.g., [61-63]) and precise knowledge of the temperature, humidity and wind distribution is necessary to estimate transport by advection. The following overview on measurement techniques will be stratified into in situ techniques and remote sensing.

\subsection{In Situ Measurements}

In situ data obtained at a limited number of sites will not be able to depict the full spatial variability of atmospheric fields in mountainous terrain, although they can monitor the full temporal variability at the selected sites if they have a sufficiently high temporal resolution. In situ measurements from moving ground-based measurement platforms such as cars can partly capture the spatial variability if the platform is sufficiently maneuverable. This may become very difficult and often impossible in steep and inaccessible terrain. Airborne platforms may be the only solution to this problem and are addressed in Section 4.

\subsubsection{Surface Parameters}

All classical atmospheric (e.g., wind, temperature, humidity) and surface (e.g., surface roughness, soil moisture, soil type, land use) meteorological variables known from flat terrain can be observed in mountainous regions as well. But roughness in complex terrain must be described as 'effective roughness length' which also comprises subgrid-scale orographic effects. A good approach to assess the magnitude of the effective roughness length is to choose it so that the additional pressure drag exerted by the subgrid-scale orographic features is included [64-66]. This must be accompanied by additional topographic data such as altitude, inclination of the surface, ruggedness of the terrain, sky-view factor, and other parameters which characterize the heterogeneity of the measurement site in more detail. Without such metadata, proper interpretation of the measured data is impossible.

\subsubsection{Radiation}

Individual components of the radiation balance are typically made with high-quality, carefully calibrated pyranometers and pyrgeometers. The radiation balance in mountainous regions is complicated by a range of factors including heterogeneity of surface radiative properties, roughness elements covering a range of scales, non-uniform aerosol distributions, different vegetation covers, as well as reduced and complex sky view factors and extended shadowing [67]. These different factors may lead to surface radiation balances that differ greatly from flat homogeneous terrain [63]. Radiation measurements should be done parallel to the slope when net radiation is of interest for energy balance studies. Satellite-based radiation measurements in mountainous terrain are addressed in [68].

\subsubsection{Temperature}

Surface temperature is a critical variable in the surface energy balance that links the atmospheric and sub-surface processes. Typically, either sensors are placed on the surface in an effort to match surface radiative properties or radiative surface temperatures are measured directly [69]. With higher-speed thermal cameras, characteristics of temperature fluctuations and turbulence structures can be better understood [70,71]. Results from MATERHORN and METCRAX II indicate that this is extremely a promising technology for studying surface thermal characteristics, as well as turbulence and flow characteristics.

Temperatures in the air can also be measured by using Distributed Temperature Sensors (DTS, [72,73]). DTS systems use Raman scattering along a fiber optic beam to measure temperatures at approximately $1 \mathrm{~Hz}$ and 1-m resolution over distances greater than $1 \mathrm{~km}$. Example complex terrain deployments include MATERHORN [19] and the Shallow Cold Pool experiment [74]. The DTS technique 
is also being expanded to allow for simultaneous wind measurements [75]. Mean temperature gradients can be used to infer turbulent fluxes in the absence of high-resolution measurements.

\subsubsection{Pressure}

Near surface micro-barometer measurements in complex terrain in conjunction with turbulence measurements can help to clarify the role and interaction between wave motions, pressure drag and turbulence in stably stratified flow [76]. Analyzing pressure and turbulence signals taken in complex topography is very difficult given the lack of stationarity and hence applicability of standard processing methods. Micro-barometer networks are also very useful in identifying mesoscale flow characteristics like warm-air intrusions in the Meteor crater (e.g., [24,77], see also Figure 2). Strong warm-air intrusions into the crater were correlated with strong negative pressure differences between the crater's upper sidewalls and crater floor as well as the crater's upper and lower sidewalls (Figure 2a,c). The warm-air-intrusion events were also visible by high wind speed and turbulent kinetic energy (TKE) (Figure 2d,e).

Overall, pressure measurements can be useful to understand the mechanisms behind observed winds (e.g., [78]) and estimate their integrated effects, for example, through orographic drag (see, e.g., $[64,65]$ or $[66])$.

\subsubsection{Wind and Humidity}

Wind and humidity measurement techniques in mountainous terrain do not differ substantially from such measurements in flat terrain, but the interpretation of the data may be different and much more difficult. In particular, wind data can only be understood when the exact topography near the measurement site is well known. Wind direction is heavily influenced by topographic features. Mountain slopes guide the horizontal winds parallel to them (also known as channeling in valleys). Thermally driven slope, in-valley and out-valley flows modify wind speed and direction further and can provoke diurnal periodicities. Larger-scale pressure gradients can produce, e.g., gap flows through narrow passages and foehn-type flows over mountain ridges (see [79] for further details).

\subsubsection{Eddy-Covariance Measurements and Post-Processing}

As the spatial variability of energy exchange at the Earth's surface is one driving force for mesoscale transport and vertical mixing processes, substantial effort has been put into turbulence measurements and post processing techniques in general and for complex terrain (e.g., [80]). Over complex terrain, representativeness of measurements influenced by heterogeneous terrain and the orientation of the instrumentation over inclined surfaces are the main issues. That means best practices and the impacts of different instrument configurations and processing methods are relevant open questions. The current standard method for making high-frequency turbulence measurements in complex terrain is applying the eddy-covariance method by utilizing sonic anemometry/thermometry for measurement of all three components of velocity and sonic temperature in conjunction with other fast response scalar measurements (e.g., for humidity and trace gases). Many papers and text books have been written on the appropriate treatment of turbulence data (see e.g., [81-83]). However, most of the literature focuses on flux corrections that are related to horizontally homogeneous and non-complex terrain where Monin-Obukhov similarity assumptions are reasonably well approximated. In complex terrain, these assumptions may be invalid and require different methodologies $[84,85]$. For example, today most researchers account for local streamline deformation using either double or triple rotations [86] or planar fit methodology [87]. In the case of a tilt angle caused by upwind terrain conditions varying with the wind direction, sector-dependent algorithms, denoted as expanded, optimized, or continuous planar fits, have been proposed (e.g., [88-90]). References [85,88-90] also compare and assess the different algorithms and provide some guidelines for applications. Nevertheless, appropriate coordinate transformations are still uncertain, especially for truly complex, three-dimensional orography where additional terms in the equations of motions must be considered. 
That means no single best approach exists for all sites and conditions [85]. These authors suggest that measured turbulent fluctuations must first be brought into a Cartesian coordinate system $(x$-axis pointing into the mean flow direction and the $z$-axis normal to the surface).
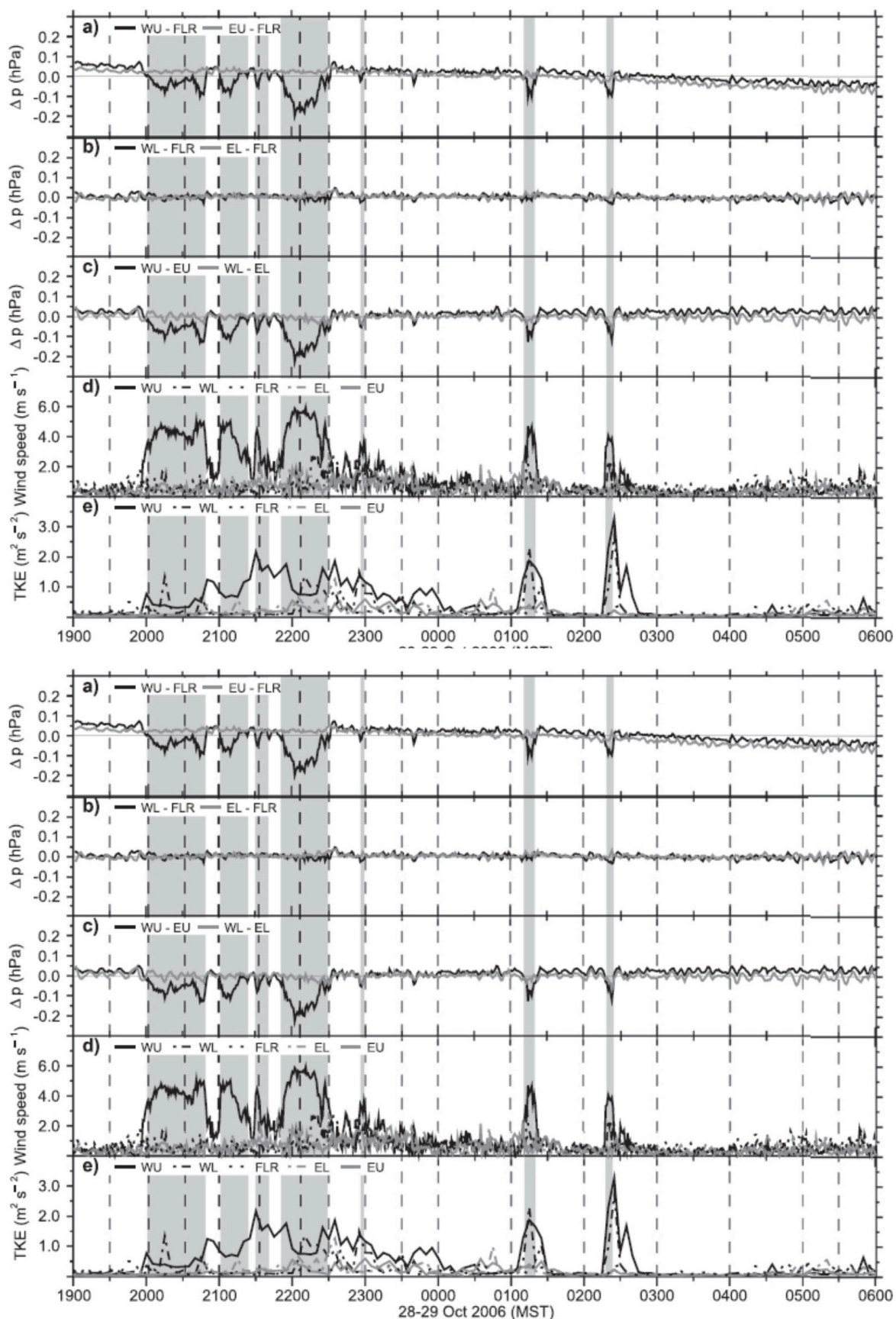

Figure 2. Time series of the 1-min-average (a) pressure difference $\Delta p$ between crater's western upper sidewall (WU) and crater floor (FLR) and between crater's eastern upper sidewall (EU) and FLR, (b) $\Delta p$ between crater's western lower sidewall (WL) and FLR and between crater's lower sidewall (EL) and FLR, (c) $\Delta$ p between WU and EU and between WL and EL and (d) terrain-following wind speed and (e) 5-min-averge turbulent kinetic energy (TKE) at $5 \mathrm{~m}$ above ground on 28/29 October. The grey dashed vertical lines mark the launch times of tethersondes soundings, the black dashed vertical lines indicate soundings with warm-air intrusions, and the grey-dashed areas indicate times with warm-air intrusion as determined from pressure and wind measurements (from [77], @American Meteorological Society. Used with permission). 
On a sloped surface, [85] note that friction associated with turbulent fluctuations will lead to a flux of slope parallel momentum in the normal to the surface (Figure 3a). Hence, the local normal seems to be the appropriate coordinate direction for this 'vertical flux' of momentum. For the sensible heat flux, [85] assume that the perturbation isentropes, $\theta^{\prime}$, are parallel to the local surface on a slope (Figure $3 b$ ) so that very close to the surface the local normal again is appropriate for the sensible heat flux. However, the heat flux is driven by buoyancy that is directed in the vertical direction, irrespective of the underlying slope. Therefore, at a 'certain height' the dominant sensible heat flux is 'vertical' rather than normal to the local slope. However, the level of the 'certain height' is not yet well defined [85]. Figure 4 shows the impact of near-surface vertical and slope-normal installed sonic anemometers to calculate the sensible heat flux [85].

Additional difficulties arise in complex orography when trying to measure 'representative fluxes'. Long-term turbulence sites have been installed in the Inn Valley in Austria to address this issue [32]. Flux stations need to be distributed in the area of interest both horizontally and vertically (e.g., to measure momentum and sensible heat fluxes) adding dramatically to cost and complexity of experiments. Furthermore, over mountainous terrain there can be a substantial spatial variability of surface turbulent fluxes with respect to the time and maximum of the daily cycle [62]. These differences are largely controlled by the available energy. For that, lower-cost instruments that quantify small-scale processes and cover the small-scale spatial variability of fluxes would be beneficial. Furthermore, turbulent measurements, even at the top of small towers, are not necessarily representative of the surface conditions since horizontal and vertical advection processes could be important. Reference [62] at least found some evidence for that. Reference [91] also partly attributed advection processes to be responsible for the underestimation of turbulent fluxes over heterogeneous terrain.

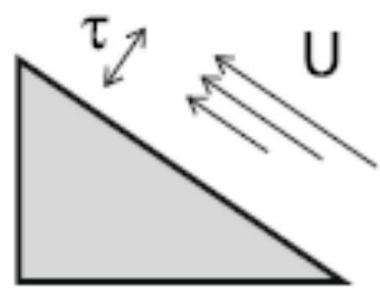

mechanical

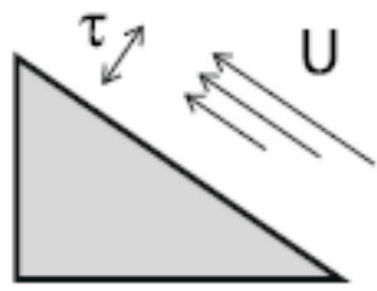

mechanical

(a)

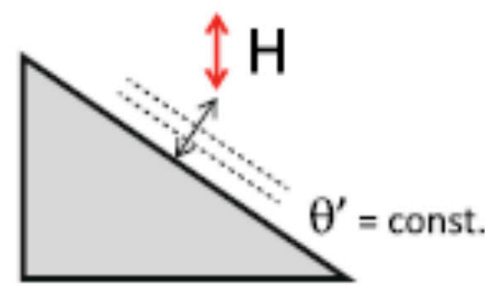

thermal

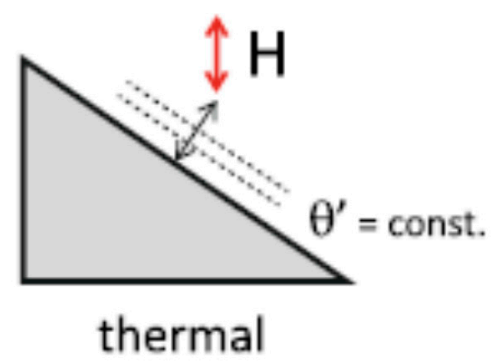

(b)

Figure 3. Definition of local coordinates over (ideally) sloped terrain, in (a) for mechanical (left) and (b) thermal (right) properties. In (a) $\tau$ corresponds to the longitudinal component of shear stress (frictional stress), $\mathrm{U}$ is the longitudinal wind component, in (b) $\theta^{\prime}$-lines denote isolines of potential temperature perturbations (around a mean state) and $\mathrm{H}$ is the sensible heat flux (from [85], Copyright: Open Access, CC-BY).

\subsection{Surface-Based Remote Sensing}

Remote sensing techniques usually capture either path-averaged or range-resolved data along the observational path of these instruments. This path is either the path of the emitted beam of active remote sensing instruments or the view angle of passive instruments. The full variability of atmospheric fields can only be observed, if range-resolving instruments are run in a scanning or 
imaging mode. The repetition rate of these scans once again determines whether the full temporal variability of atmospheric fields can be captured. To estimate the exchange and transport of moisture, heat and mass, knowledge of the spatial distribution and temporal evolution of humidity, temperature and wind is crucial. While getting a full three-dimensional picture of the atmospheric quantities with a sufficient temporal and spatial resolution to resolve turbulence is not yet achieved-and maybe never will be, remote sensing instruments are able to at least partly provide the required information. The three-dimensional wind field can be obtained by active remote sensing using instruments like Doppler lidars. Profiles of temperature and humidity—and partly even information on the spatial distribution-are available from active remote sensing instruments like Raman lidars and Differential Absorption Lidars (DIALs) and passive remote sensing instruments like microwave radiometers and infrared spectrometers. An overview on remote sensing measurement techniques is given in [12] and a special compilation of surface-based remote sensing techniques for the atmospheric boundary layer is available in [92]. In the following, an overview of some passive and active remote sensing instruments and their application to study exchange and transport processes over complex terrain is given.
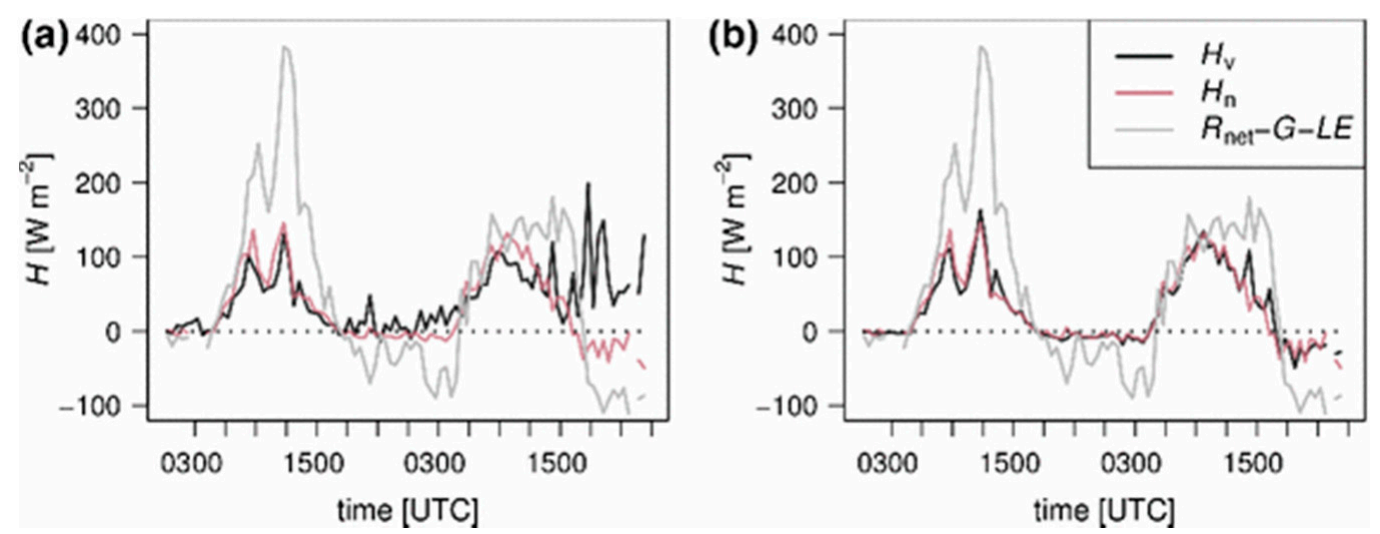

Figure 4. Daily cycle of sensible heat flux, $\mathrm{H}$, at 2-m height when a mobile tower with two sonic anemometers was operated on a slope: one installed vertically $\left(\mathrm{H}_{\mathrm{V}}\right)$ and one slope-normal $\left(\mathrm{H}_{\mathrm{n}}\right)$. Data are from two consecutive days with weak synoptic forcing ('purely' thermally driven valley and slope wind regime). (a) Values of heat flux from both sonic orientations, rotated only into the mean wind. Coordinate rotation for $w$ was only applied to slope-normal orientation. (b) Values of heat flux from both installations, after double rotation was applied to both. The remaining terms of the energy balance closure (net radiation $R_{\text {net }}$ minus ground heat flux, $G$, and latent heat flux, $L E$ ) are also plotted as a reference (from [85], Copyright: Open Access, CC-BY).

\subsubsection{Passive Remote Sensing}

Passive remote sensing by surface-based microwave radiometers provides data of temperature and humidity with moderately high temporal (order of seconds to minutes) but relatively low spatial (order of a hundred of meters) resolution. From measured brightness temperatures, atmospheric quantities are obtained with retrievals. A good overview of this technique is given by $[93,94]$. To enhance the vertical resolution of temperature profiles in the boundary layer, so called boundary-layer scans are performed [95]. This method implies horizontal homogeneity of the atmosphere, which is generally not a valid assumption over mountainous terrain. However, [96] show that one-dimensional variational (1D-VAR) retrieval techniques combining microwave radiometer measurements with $1 \mathrm{~h}$ forecasts from a numerical weather prediction model is able to provide a good retrieval of low level temperature inversion in complex terrain (see Figure 5). Over complex terrain, elevated inversions are common (see Figure 1 as well). These are challenging to observe with a microwave radiometer due to the coarse vertical resolution decreasing with altitude. Reference [97] developed specialized algorithms to improve the representation of these inversions. Scanning systems 
allow for the identification of the spatial distribution and evolution of humidity. In the absence of synoptic scale changes, a moisture increase in an elevated layer usually indicates that air originates near the Earth's surface. The moisture distribution can therefore be used as an indicator for convective and mesoscale transport processes. Reference [44] used a scanning microwave radiometer to study the transport of water vapor with thermally driven circulations over the mountainous island of Corsica. An example of the spatiotemporal integrated water vapor, IWV, distribution measured with a scanning microwave radiometer located at a valley floor is presented in Figure 6. IWV measured during azimuthal scans reveals that higher IWV values occur over the surrounding ridges than over the valley indicating an upward transport of moisture with slope winds.

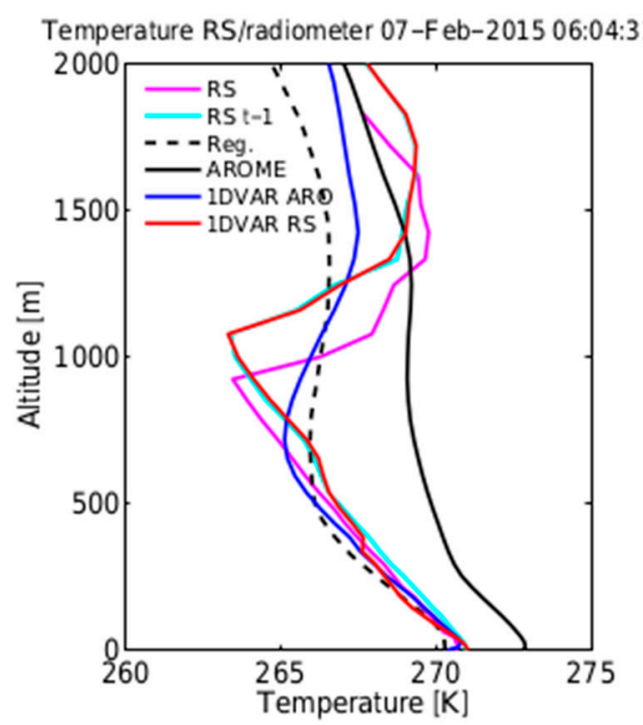

(a)

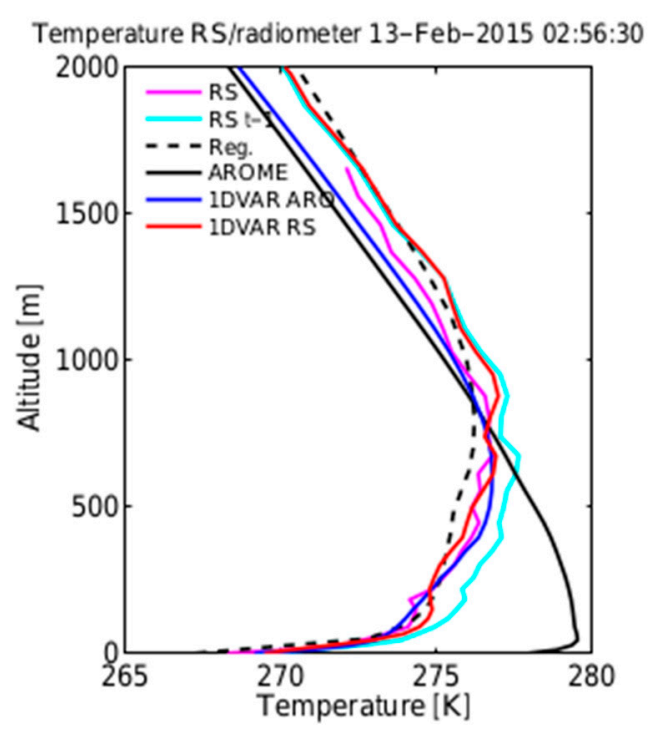

(b)

Figure 5. Vertical profiles of temperature in the Arve valley (Passy-2015 field experiment) during convective conditions on 7 February 2015 at 06:04 UTC (a) and during stable conditions on 13 February at 02:56 UTC (b). Comparison between radiosonde profiles (magenta), linear regression (dashed black line) and 1D-VAR from AROME model forecasts (blue), 1DVAR from previous radiosonde (red). Background profiles corresponding to either the $1 \mathrm{~h}$ AROME model forecast (black) or the previously launched radiosonde (cyan) are also shown (from [96], Copyright: Open Access, CC-BY).

Taking advantage of the Global Positioning System (GPS) network, information on IWV can be derived as the tropospheric delay of the GPS signal is significantly impacted by humidity (e.g., [98]). As there is a rather dense network of GPS receivers all over the world, this technique allows the detection of mesoscale variations in space and time of IWV and may therefore be useful to trace the moisture transport over complex terrain. This was demonstrated in, e.g., [99] for the mountainous island of Corsica.

\subsubsection{Active Remote Sensing}

Different instruments based on different physical measurement principles exist for measuring atmospheric quantities such as temperature (e.g., Raman lidar, Radio Acoustic Sounding System (RASS)), humidity (e.g., Raman lidar, differential absorption lidar (DIAL)), wind (e.g., sodar, radar wind profiler, Doppler lidar), clouds (e.g., cloud radar) and rain (e.g., rain radar), where each instrument has advantages and disadvantages. A comprehensive overview is given by [12,60,92]. Active surface-based remote sensing systems have been used in complex terrain for several decades.

Scintillometry, as a technique for providing spatially-integrated turbulence data, has been used successfully in complex terrain on several occasions [32,100,101]. Single wavelength methods typically yield path averaged fluxes or, more fundamentally, structure parameters over distances typically 
ranging from $500 \mathrm{~m}$ to $7 \mathrm{~km}$. Bichromatic systems, or combinations of infrared and microwave scintillometers, have been used to provide estimates of sensible and latent heat fluxes over idealized and urban terrain [102-104]. Concerning scintillometry, difficulties in complex terrain are due to the fact that standard scintillometry methods assume the validity of Monin-Obukhov similarity a priori. Depending on the site, this may be a reasonable or quite invalid assumption. More understanding of the method is needed to better integrate the measurements in complex terrain [103]. Scintillometers can also provide an estimate of integrated cross-valley wind (e.g., [100]).
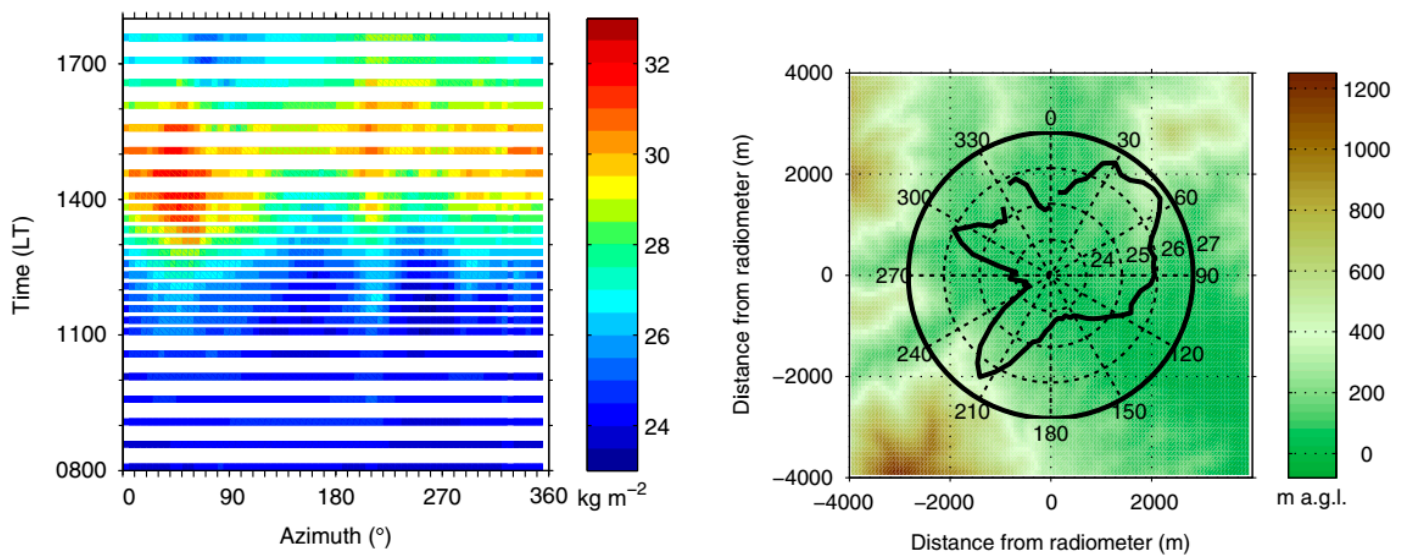

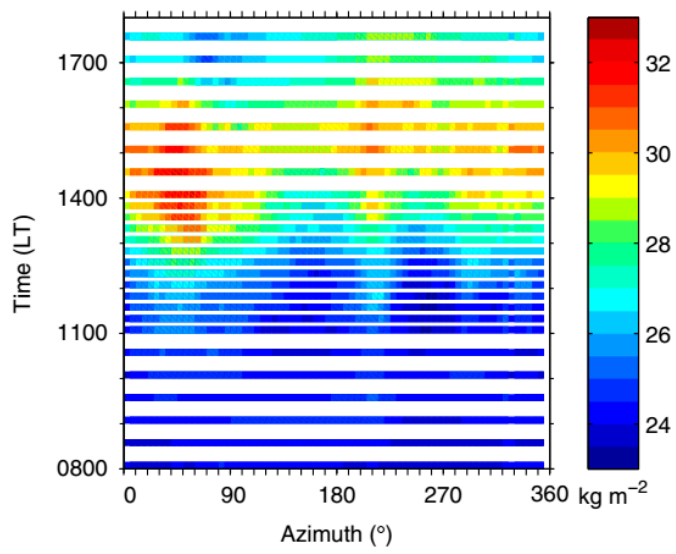

(a)

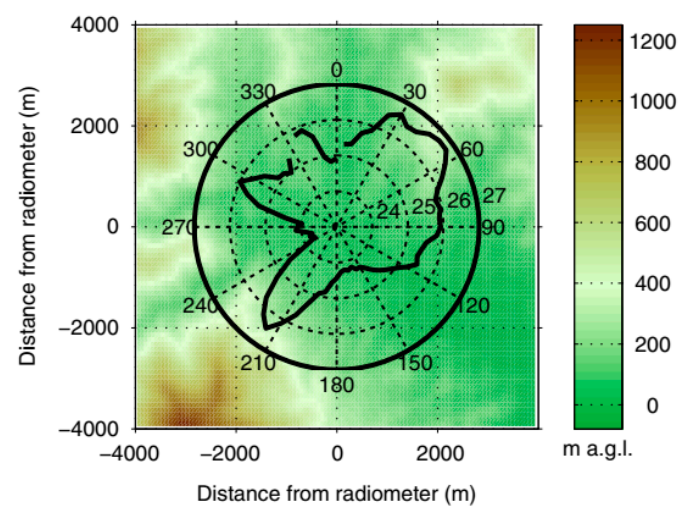

(b)

Figure 6. Azimuthal time plot of IWV (integrated water vapor) (a) and polar plot of IWV with underlying orography at 1200 Local Time (LT) (b) at Corte in Corsica on 19 August 2012 for an elevation angle of $19.8^{\circ}$. IWV was measured by a microwave radiometer. In $(\mathbf{b})$, the orography is displayed in meters above ground relative to Corte (from [44], Reprinted by permission from Springer).

Profiles of temperature can be obtained from RASS's and Raman lidars and humidity profiles from Raman lidars and DIAL's [105]. In contrast to the profiles from the passive microwave radiometer, the vertical and temporal resolution of these profiles is sufficient to resolve both elevated inversions and small-scale variations on the turbulent scale but limited to clear-sky conditions and nighttime for the Raman lidar [106].

Wind measurements by remote sensing in complex terrain involve a major difficulty. Wind vector measurements with active remote sensing instruments (Doppler lidars as well as sodars and radar wind profilers) require at least three independent measurements for the three wind components. A single surface-based device has to do this by looking into three or five separated volumes of air or conical scanning and subsequent calculation of the wind components. State-of-the-art Doppler lidars are fast scanning and have a temporal resolution of $1 \mathrm{~s}$ or even less and a spatial resolution along the beam of a few tens of meters. Thus, they are powerful tools to study turbulent and mesoscale processes. 
But, the calculation of the wind components from remote sensing data assumes straight streamlines in the air volume containing all separate measurement volumes. Any curvature of the streamlines will lead to systematic biases [107]. Two solutions might help: either correct biased data a posteriori with the help of flow models which give the correct curvature of the streamlines [108] or apply the dual- or triple-Doppler technique to radial velocity measurements from multiple scanning lidars. The idea behind the dual- or triple-Doppler technique is that two or three physically separated scanning Doppler lidars point at the same volume of air from two or three different directions. This allows for the retrieval of two or all three wind components in the same air volume. Sophisticated and complex scan strategies and patterns have been developed and applied in the past including the virtual tower technique where profiles of the two or three dimensional wind are obtained (e.g., [109-111] or coplanar scans, where two Doppler lidar perform coordinated scans in a plane which allows the retrieval of the two-dimensional wind field in this plane (e.g., [112-114]. The application of the dual- or triple-Doppler retrieval requires a high degree of synchronization and accuracy to assure that the lidars simultaneously sample the same air volumes. One possible option to achieve this is given by the Windscanner system which was developed at the Technical University of Denmark (DTU, $[115,116])$. The errors of dual-Doppler lidar measurements resulting from the finite scan duration and temporal and spatial averaging are assessed by [117]. The dual-Doppler retrieval allows the spatial distribution and temporal evolution of flow structures ranging from the micro- to the mesoscale to be studied. As the temporal resolution of Doppler lidars is of the order of seconds or even less, it is even possible to derive all three components of atmospheric turbulence in an air volume depending on the scan strategy. The dual- or triple-Doppler lidar retrieval has been utilized, e.g., in wind energy applications to study wakes behind wind turbines (e.g., $[112,118,119])$ and for the assessment of wind conditions at a bridge in a Norwegian fjord, (e.g., [120]). During the recent ScaleX [25] and Perdigão [121] field campaigns, the technique was applied to study flow patterns over mountainous terrain.

Using the example of Doppler lidar measurements over hilly terrain in South-Western Germany, we illustrate how virtual towers help to gain insight into the mesoscale variability of the horizontal flow. Two powerful lidars were installed on opposing slopes around $6 \mathrm{~km}$ apart. Using a control software developed at Karlsruhe Institute of Technology (KIT, [122]), two lidars performed coordinated scans and placed 6 virtual towers in the valley and near the slopes measuring for $10 \mathrm{~s}$ at each level (Figure 7). The whole cycle was repeated every $20 \mathrm{~min}$ which provided insight into the spatial variability during each cycle as well as the temporal variability from consecutive cycles. Spatial differences occur at lower layers likely related to topographic effects. $[123,124]$ used the dual-Doppler retrieved wind field in a vertical plane to study the complex flow structure in a Meteor crater during the METCRAX II field campaign (Figure 8). One lidar was placed on the rim and the other one at the crater floor. Due to the depth-width ratio of the crater it was possible to retrieve the horizontal and vertical wind component in the plane, which allowed to distinguish different flow regimes in the crater like a bifurcation and warm air intrusion phase. Besides the dual-or triple Doppler retrieved wind fields, single Doppler lidar measurements can also provide a good overview of the three-dimensional flow field if certain conditions regarding e.g., instrument location, topographic shape and air masses characteristics are fulfilled. For example, [46] used radial velocity and backscatter measurements from horizontal and vertical scans to study small scale circulations and their impact on transport of pollutants in a narrow Alpine valley close to the Mont Blanc (Figure 9). 


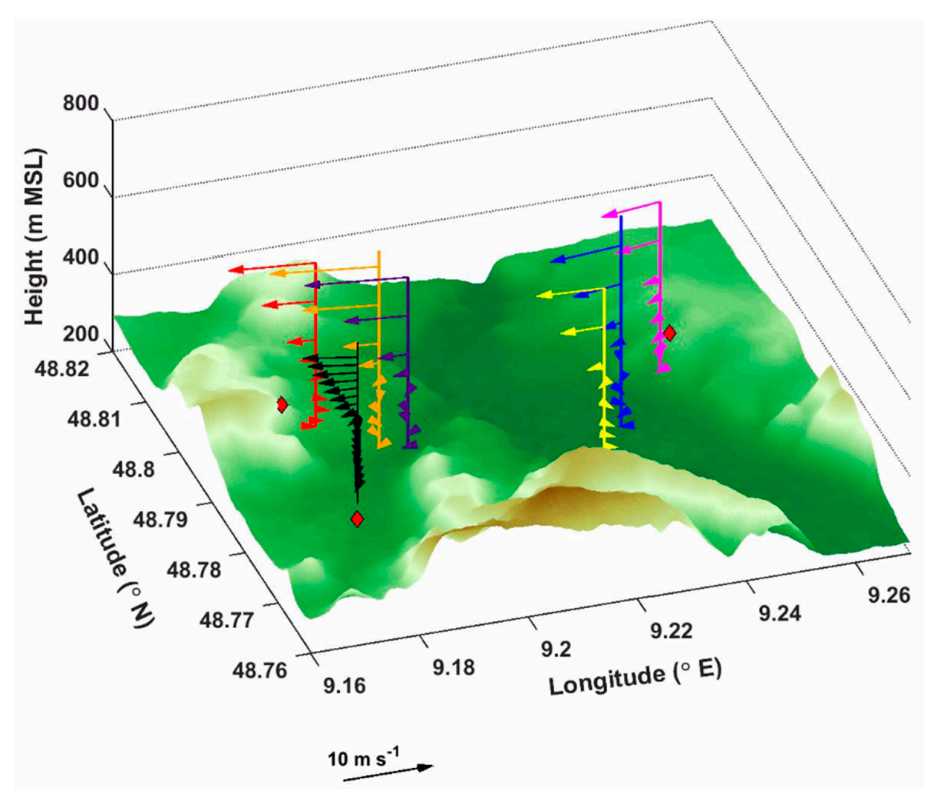

Figure 7. Vertical profiles of horizontal wind in the Neckar valley near the city of Stuttgart in South-Western Germany based on the virtual tower technique. The position of the two Doppler lidars on the slopes performing coordinated scans to place the virtual towers (colored profiles) are indicated by red diamonds. In addition, the horizontal wind profile calculated from a third lidar using the Velocity Azimuth Display (VAD) technique is shown in black. While the flow is rather homogeneous at higher altitudes, some spatial differences occur in lower layers related to the impact of the topography.

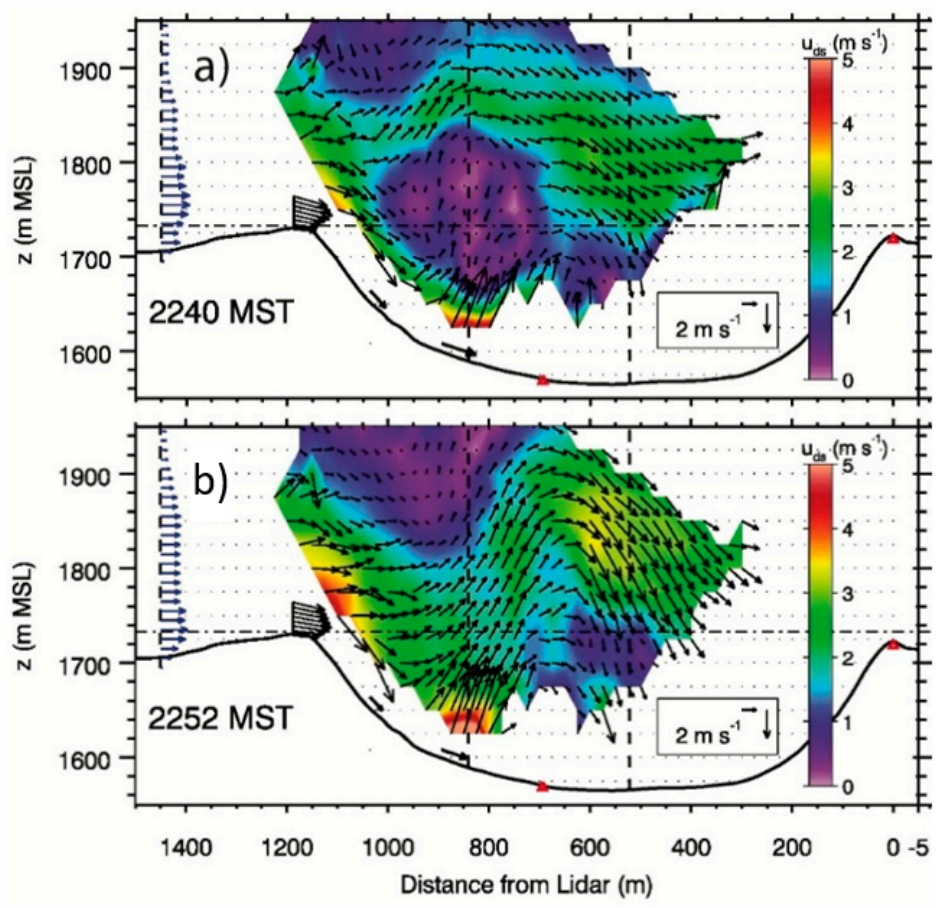

Figure 8. Illustration of an abrupt change in flow structure between the bifurcation and warm air intrusion phases from 2.5-min-mean dual-Doppler wind retrievals at (a) 2240 and (b) 2252 Mountain Standard Time (MST). The positions of the two Doppler lidar (crater floor and on the rim), which were used for the dual-Doppler retrieval, are indicated by red dots (from [124], (CAmerican Meteorological Society. Used with permission). 


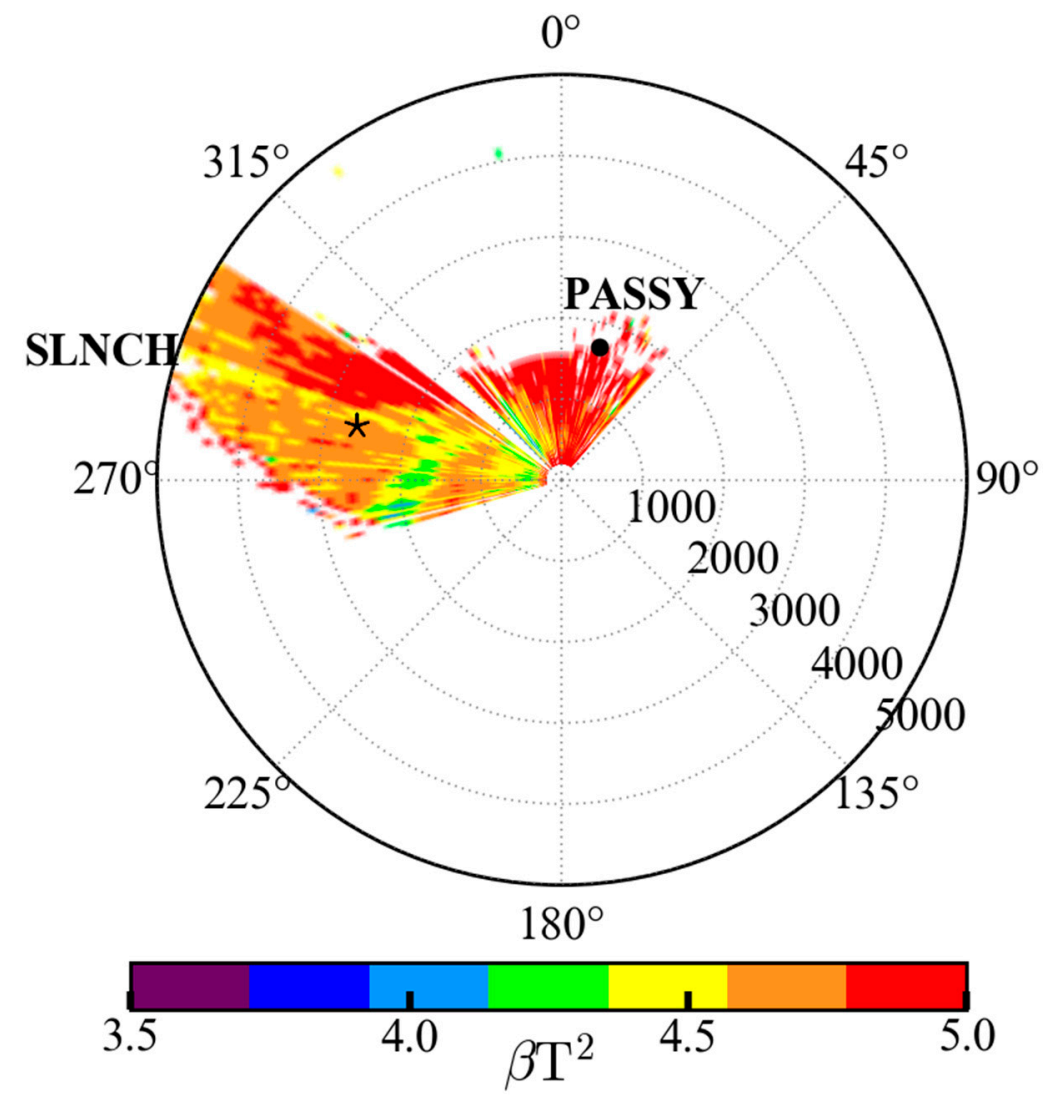

Figure 9. Illustration of the use of scanning Doppler wind lidar corrected backscatter signal to retrieve information on a flow perpendicular to the lidar line of sights during the Passy-2015 field experiment in the Alps. The lidar is located at the center $(0,0)$. The flow coming from the Megève tributary valley on the southern side can be seen (in green) as it generates less backscatter signal than the different surrounding air mass (in red) in this part of the Arve Valley (from [49], Copyright: Open Access, CC-BY). SLNCH: city of Sallanches; PASSY: city of Passy; $\beta \mathrm{T}^{2}$ : corrected backscatter signal.

\section{Airborne and Satellite Observations}

Bridging the scales between local in situ, local vertical or 3D, and regional scale investigations, mobile in situ or remote sensing techniques are necessary. A larger number of airborne measurement platforms are available today. Depending on their maneuverability and endurance, they may be able to permit the instruments mounted on them to capture the full spatial and temporal variability of the atmospheric fields. Among these platforms are: balloons and radiosondes, tethered balloons, unmanned aerial vehicles (UAV) and aircraft.

\subsection{Radiosondes and Tethered Balloons}

Radiosondes and tethersondes are used for profiles of mean meteorological parameters (i.e., temperature, humidity, wind). The only inner-alpine radiosonde station in the European Alps is Innsbruck. However, it cannot be expected that data from a radiosonde in a valley center is representative of the conditions in the lower atmosphere over adjacent ridges, slopes or even along the valley floor (e.g., [97]). Considerable spatial variability of dynamic and thermodynamic parameters also affect the spatial variability of added value quantities like convective available potential energy (CAPE) and convective inhibition (CIN) so that mesoscale radiosonde networks or mobile radiosonde stations are beneficial to capture the full atmospheric heterogeneity over mountainous terrain (e.g., [125]).

In addition, recoverable radiosounding systems can be very useful for reducing costs to allow soundings more frequently to capture rapidly evolving lower tropospheric conditions in mountainous areas [126,127]. They have been recently used during the Passy-2015 field experiment [30] and allow 
a very efficient and cost-effective investigation of the boundary layer cycle during persistent inversion episodes in a narrow Alpine valley. Sounding intervals of down to $1 \mathrm{~h}$ were applied during the Dynamics-Aerosol-Chemistry-Cloud Interactions in West Africa (DACCIWA) field campaign to study the nocturnal and convective boundary layer [128].

Tethered balloons and kites bridge the gap between in situ measurements from towers and radiosondes. They can provide profiles of up to a thousand meters above ground from various locations as long as mean winds are not too strong (below about $10 \mathrm{~m} \mathrm{~s}^{-1}$ ). Besides mean meteorological parameters, they can also be used for turbulent and fluxes measurements as they allow for larger payloads than radiosondes (e.g., [129]). Furthermore, tethered balloons allow continuous measurements at a fixed height, or repeated high-resolution scanning of vertical profiles when operating them with a slow ascent/descent rate.

\subsection{Aircraft in Situ}

Airborne platforms currently available range from large manned aircraft to remotely piloted unmanned aerial vehicles (see Section 4.4). Aircraft have been used over many years to measure in situ wind fields and other meteorological parameters as well as for remote sensing [130-133]. Such measurements cover scales from several hundred $\mathrm{km}$ at cruising speeds of up to $100 \mathrm{~m} \mathrm{~s}^{-1}$ from large aircraft to local, a few hundred meters scale, at speeds of a few to zero $\mathrm{m} \mathrm{s}^{-1}$ from multi-copters and small model-aircraft. The optimum platform is dependent on the required scale and resolution of the measurements. Small environmental research aircraft (SERA) with a payload of up to $150 \mathrm{~kg}$ and operation by one pilot/scientist are one of the most versatile platforms. Aircraft are also often used for dropsonde release. A major difficulty here is to get permission even over rural environments.

Large aircraft, as used normally for remote sensing, are fast and useful for covering long distances; however, they are not as maneuverable and cannot be used in narrow mountain valleys. Also they are not designed for low elevation flights and their operation range is typically in the upper half of the PBL or even above. Currently, the most promising and most cost-effective solution would be small environmental aircraft like ultralights or motorized gliders $[42,53,134,135]$. Such aircraft can carry between 50 and $\sim 120 \mathrm{~kg}$ of scientific payload, and can fly up to six hours giving a horizontal range of 600 to $1200 \mathrm{~km}$. As they can fly also low and slow, down to $30 \mathrm{~m}$ above ground level (agl) and $20 \mathrm{~m} \mathrm{~s}^{-1}$, they are suitable platforms for high resolution earth observation and allow for extending the scales from local measurements (TERENO, [25]) to regional scale observations ([136] or [28] for COPS. Even eddy covariance measurements to determine latent and sensible heat exchange are possible from ultralights [137]. Also, as they are participating in civil aviation conventionally they do not require any special permits. Such permits would be only needed in case that they are supposed to fly below 'standard' safe altitude of $\sim 500 \mathrm{ft}$ or $\sim 150 \mathrm{~m}$ agl (an altitude range that may be covered by UAV flights (unmanned atmospheric vehicles, see Section 4.4 below)). The optional payload allows to carry both, in situ instrumentation for radiation, atmospheric state variables, turbulent fluxes and micrometeorology, aerosols, trace gases and also remote sensing in one package in a fully equipped airborne observation platform [134,138]. Although it is always beneficial to miniaturize sensors for such applications, even some full size standard instrumentation like fast laser detectors (QCL) Laser or hyperspectral scanners can be flown [42,139]. To extend the number of parameters measurable, miniaturized instruments were developed for these small aircraft within the last decade which nowadays also even applicable for UAV research $[134,140]$. Residual kriging has been used successfully to analyze airborne in situ measurements in Alpine valleys [141].

\subsection{Airborne Remote Sensing}

Data needed for high-resolution observation of transport and exchange processes in mountainous terrain include: three dimensional winds, temperature and humidity over the whole depth of the boundary layer, three-dimensional surface structures like orographic structures, and also small-scale surfaces properties like vegetation type and coverage, which affect roughness, temperatures and 
trace gas exchange. These data are accessible via active or passive remote sensing. While satellite observations generally reach neither the horizontal resolution required for the investigation of transport processes nor the vertical resolution needed for the assessment of vertical exchange processes, other airborne platforms have to be used. Active techniques are applied for certain parameters like vertical profiles of winds or aerosols from airborne lidar applications [142], indirect techniques to derive spatial surface properties from a variety of different techniques based on optical (spectral) information [143]. A special application is the measurement of soil water using radar techniques (PLMR: Polarimetric L-band Multi-beam Radiometer \& Thermal Imager, [133]).

Today's SERAs are able to accommodate several different techniques at the same time. For example, laser scanning for surface topography, hyperspectral and thermal infrared cameras and also in-situ techniques for turbulent sensible and latent heat fluxes can be flown the same time on one single platform (see, e.g., [136,144]). The smaller unmanned systems (UAVs, see the next subsection) in contrast can fly only one sensor or a limited parameter set.

SERAs are often used from agricultural private landing strips for example in Australia and Africa and were even operated from a country road in Inner Mongolia [131]. Figure 10 shows results from a manned ultralight aircraft flying in Inner Mongolia with a combination of in situ radiation, turbulent flux and aerosol sensors with thermal infrared camera and single downward pointing temperature sensor for surface temperature and variability characterization. The aim of these studies was an investigation of the soil water content from the early morning development of the surface temperature, radiation flux and latent energy fluxes.

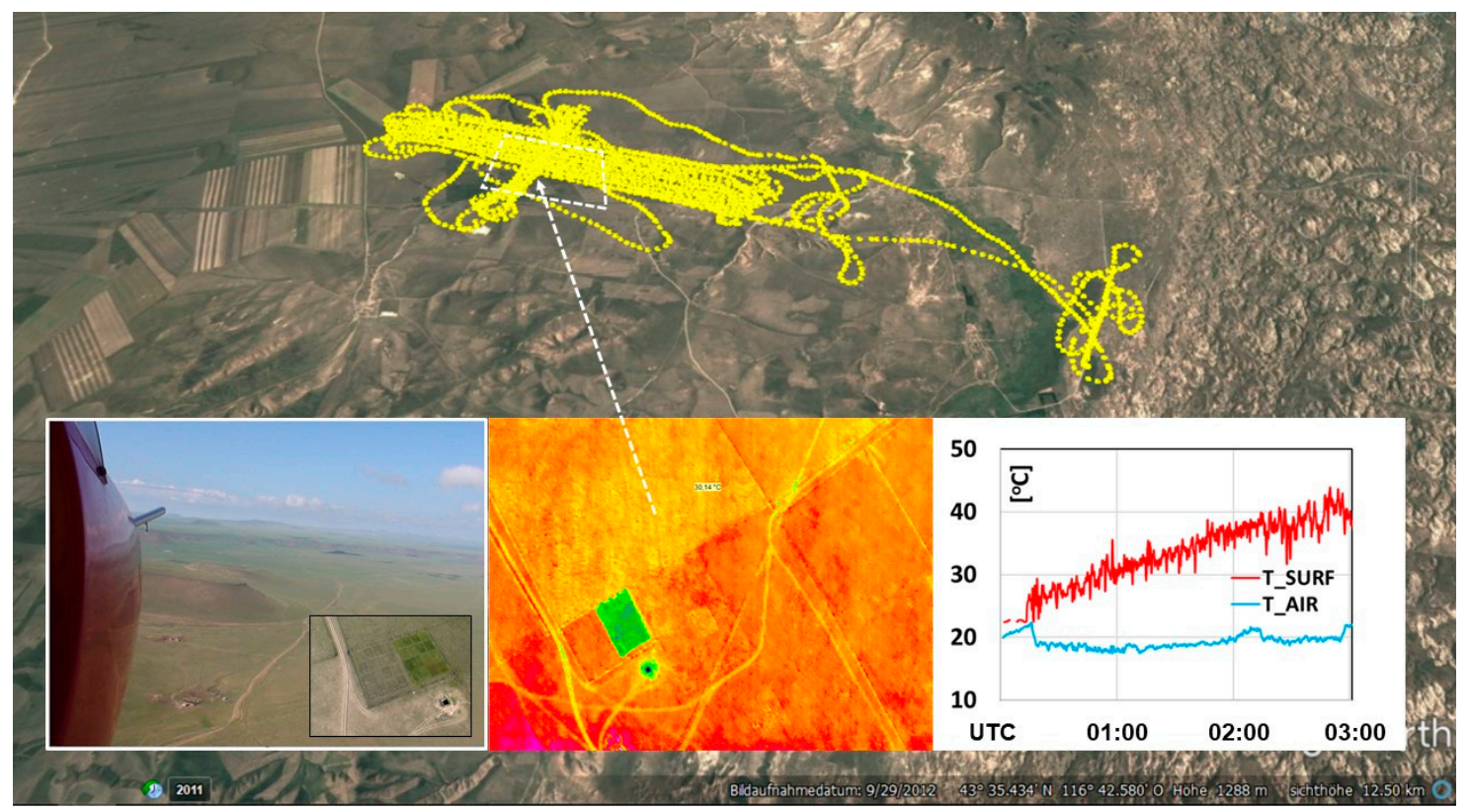

Figure 10. Flight over a grassland observation area in Inner Mongolia, China, for surface temperature measurements. The change of the surface temperature with the incoming shortwave radiation is proposed to be an indicator of soil water content. Flight altitude $500 \mathrm{~m}$ above ground level (agl) over complex terrain in partially volcanic environment. High resolution $(640 \times 480)$ thermography (center panel) shows spatial variability in surface temperature and dependence on vegetation cover. Right panel shows the $3 \mathrm{~h}$ surface temperature (T_SURF) trend and temperature at flight elevation (T_AIR).

\subsection{UAVs and RPAS}

In recent years, both UAVs and multicopters have become frequently used flying platforms for measurements in atmospheric research for vertical and horizontal applications [140,145,146]. UAVs can cover a vertical and horizontal range of several kilometers and therefore are suitable 
for investigations on horizontal inhomogeneities and transports across them throughout the boundary layer. Multicopters offer flexible maneuverability at low flight speed and the possibility of capturing detailed vertical profiles by hovering (i.e., no horizontal movement). National regulations and airspace limitations have to be obeyed for both of them in flat as well as in complex terrain. Current limitations issued by national aviation and legislative authorities comprise, e.g., flying restrictions beyond line of sight (which can happen more often in mountainous terrain), restrictions for operation in civil aviation airspace ( $>150 \mathrm{~m} \mathrm{agl}$ ) and weight limits. Miniaturization of sensors is in progress with optical (hyper) spectral sensors currently getting into the weight and power consumption range, allowing using even these very small airborne platforms. One of the major advantages of the UAVs are the possibility to operate in very remote places without the need for aviation infrastructure like runways or landing strips and also the ability to flight at very low altitude. On the other hand, endurance of UAVs and multicopters is limited by the capacity of the batteries and is in the order of 15 to $30 \mathrm{~min}$. Replacing used batteries by loaded ones immediately after landing may help to cover longer boundary layer developments, but requires extra sets of batteries and personnel.

Reference [147] demonstrated the utilization of fixed-wing UAVs for measurements of meteorological variables, i.e., air temperature, humidity and wind, up to $1600 \mathrm{~m}$ agl. In addition, [148] implemented radiation and aerosol size distributions sensors, [149] focused on ultrafine particles and [150] showed the possibility of turbulence measurements. Their applications include meteorological and air quality measurements, e.g., particulate matter [151] or air samples for analyses of chemical composition [152], but on a smaller scale of several hundreds of meters. In addition, [153,154] showed that the onboard flight control sensors can be used to derive wind estimates from a multi-copter's attitude control data. UAVs or RPAS (remotely piloted aircraft systems, see e.g., [155]) are used for quantifying turbulent fluxes and mean variables in the boundary layer. The use of these platforms is still fairly new and the use of simultaneous RPAS is just becoming possible and will be useful in upcoming field campaigns. RPAS have been used in mountain terrain experiments such as along idealized slopes to monitor mean variables as well as turbulence quantities such as $C_{T}{ }^{2}[19,156]$. Among their main advantages are the ability to fly at very low altitude (i.e., between a few $\mathrm{m}$ above ground and $150 \mathrm{~m} \mathrm{agl}$ ), the ability to operate in remote places without aviation infrastructures, the ability to track atmospheric phenomena such as clouds and flight nearby or within clouds (e.g., [157]) and the ability to use an automatically guided fleet of UAVs to sample the atmosphere (e.g., [158]). Nevertheless, the up to now not yet solved problems to fly in civil aviation airspaces restrict UAVs to certain locations and predefined flight patterns, thus making currently the use of UAVs probably less flexible than small environmental aircraft (SERAs).

\subsection{Satellite-Borne Remote Sensing}

Satellites enable the operation of instruments for passive and active sounding of the entire atmosphere. Their major advantage is that they see large areas at the same time. One of the disadvantages of satellites in lower orbits (e.g., such on polar orbits) is that they are fast moving so that they pass quickly and revisit one and the same site only at a very limited number of instances. This does not happen with geostationary satellites. They fly at about $36,000 \mathrm{~km}$ above the Earth's surface and thus have a very limited horizontal resolution which is not fitting to the detailed structures of complex terrain. Thus satellites will be of only limited use in mountainous terrain research, although, at least, the detection of mountain-induced convection is feasible from satellites. For inaccessible areas satellites may be the only option at all to obtain data.

Satellite sounding is a mostly passive sounding based on weighting functions which is usually hampered by very limited vertical resolution. The analysis of near-surface data from satellite-borne instruments is additionally complicated by the usually large returns from the solid Earth surface. The large complexity and inhomogeneity of mountainous terrain will make it very difficult to filter out surface returns reliably. The reader is referred to Section 3.1 in [105] for a recent summary of the abilities of satellite remote sensing. 
However, several recent programs could be of interest for mountain meteorology. The global coverage for winds of the recently launched Aeolus (see for example [159]) satellite may provide new information on the large-scale impact of mountains. Daily 500-m snow cover information provided by the Aqua and Terra MODerate resolution Imaging Spectroradiometer (MODIS, see for example [160]) and the Sentinel-2 satellites [161] can provide information on land cover at a resolution up to $10 \mathrm{~m}$ every 5 days.

\section{Remaining Challenges, Gaps and Potentials}

The possibilities to investigate turbulent and mesoscale exchange and transport processes over complex terrain have improved in the last decades; e.g., Doppler lidar systems have nearly closed the gap between small scale turbulence and the scale of convective cells and thermally driven circulations. Additionally, due to commercial application in wind energy assessments the costs of Doppler lidars have decreased significantly so that dual or even multi Doppler lidar applications are nowadays possible. Major challenges arise here from finding suitable measurement sites in complex terrain and by achieving the high necessary synchronization. In addition, even lower temporal and spatial averaging intervals and faster scan speeds have to be sought to fully resolve the spatial structure of turbulence. Nevertheless, Doppler lidars provide a large potential to capture the three-dimensional flow field over complex terrain, which has not been fully exploited up to now, while the three-dimensional structure of temperature and humidity is much harder to observe. So far, the only reliable option to get profiles of temperature and humidity with high vertical resolution is by use of in-situ measurements such as radiosondes, tethersondes, aircrafts and UAVs. However, these approaches suffer usually from low temporal resolution and limited sampling period. Profiles from microwave radiometers can provide complementary high temporal resolution and longer sampling period but (if used alone) suffer from relatively low vertical resolution and the inability in general to detect sharp gradients (e.g., boundary-layer capping inversions) at least above $1 \mathrm{~km}$ altitude. Although DIAL and Raman lidars can in principle provide temperature and/or humidity profiles with the necessary resolution, these systems are so far not commercially available, very expensive, and hard to maintain and operate. While analysis tools exist to interpolate data from surface stations in complex terrain [162,163], this is not possible above the ground (e.g., in the mixed layer) or of the atmospheric boundary-layer (ABL)) depth. To get highly resolved information in space and time on the temperature and humidity in the $\mathrm{ABL}$ and lower troposphere the usage of airborne platforms (UAVs, aircrafts) in combination with radiosondes/tethersondes and microwave radiometers is likely mandatory.

In particular, related to transport and exchange studies over complex terrain, the combination of different remote sensing and in situ instruments measuring different quantities is crucial to capture the relevant processes and process chains. For example, in order to study the processes leading to the evolution of moist convection over mountainous terrain, it is necessary to capture the energy exchange at the surface, continue via convection and thermally driven circulation in the ABL and also consider the exchange between the ABL and the free atmosphere. To study the evolution of moist convection over a mountain ridge, [164] use radial velocity measurements from Doppler lidar and cloud radar. Near-surface flux measurements over mountainous terrain are already prone to major challenges related to slope angle and representativeness of the site. Getting full profiles of fluxes in the ABL and lower troposphere arises even more challenges. For flux calculations, it is necessary to measure e.g., humidity or heat and wind in the same volume of air at the same time. While flux profiles are possible with tethered platforms they are limited in maximum height and in the number of measurement levels [165]. Flux profiles can also be obtained from stacked horizontal legs flown by aircraft and UAVs. However, this method is limited over mountainous terrain due to the requirement of long legs and the assumption of horizontal homogeneity along the leg. Remote sensing instruments like lidars have the potential to provide the required data. So far, only few studies present flux profiles from lidar measurements due to the large challenge of operating a Doppler lidar and DIAL or Raman lidar simultaneously. For example, [166] obtain turbulent flux profiles 
from airborne DIAL and Doppler lidar measurements. Mobile integrated observation platforms combining different remote sensing and in-situ systems (e.g., KITcube [164]), Atmospheric Radiation Measurement (ARM) mobile facility [167], CNRM mobile facility (e.g., [30]) can provide the required data and can be deployed in complex terrain for limited time periods during field campaigns. The data gathered from such integrated platforms can on the one hand be used for the evaluation of numerical weather prediction models and on the other hand used for data assimilation in Large Eddy simulation (LES) models. Over flat terrain, measurements are already combined with LES modeling within the LASSO project (LES ARM Symbiotic Simulation and Observation, [168]). This allows achieving a self-consistent representation of the atmosphere around the measurement site, which can assist in a better understanding of the measurements and processes causing the observed conditions. Applying data assimilation to measurements over mountainous terrain is a very challenging task but has large potential to improve our understanding of transport and exchange processes in the future.

\section{Conclusions and Outlook}

Scanning and range-resolving remote sensing techniques together with multiple low-cost in situ sensors and in situ and remote instruments mounted on highly maneuverable airborne platforms are probably the best instrumentation to capture the full spatial and temporal variability of atmospheric fields in mountainous terrain. Due to the low spatial representativeness of measurement instruments in complex terrain, a larger number of instruments than in flat terrain is needed to provide a full coverage of a given area. Therefore, cost of instruments is an issue.

Furthermore, the dual or triple Doppler lidar technique will help measure wind profiles at positions of virtual towers [169]. By this, wind profiles will be available from one set of instruments at several sites separated by horizontal distances of some kilometers. Application of the coplanar technique also will improve our understanding of mesoscale flow features over mountainous terrain. These techniques are important, because in complex terrain, the features of vertical profiles and flow features can vary rapidly from one site to the next, much more than in flat terrain. Further progress concerning turbulence information can also be expected from ongoing attempts testing and evaluating appropriate scanning algorithms [170].

Another parameter, which is highly variable in space and time in the mountain ABL is humidity. As humidity is very important with respect to the initiation of moist convection, its distribution is urgently needed, e.g., for assimilation in Numerical Weather Prediction (NWP) models. Therefore, the development of affordable continuous boundary layer humidity profiling systems is pushed forward in the last years (e.g., [171]).

But the small representativeness of measured atmospheric and surface data in complex terrain cannot meaningfully be overcome by pure technical solutions only (just more or better instruments per surface area). Sophisticated modeling techniques and elaborated algorithms have to be designed to be used interactively with improved measurements in order to provide reliable data which depict the full spectrum of atmospheric and surface processes taking place in complex terrain [138]. Steps towards this direction are already being taken, i.e., by exploiting high-resolution modeling capability to bridge the gap from point measurements to larger scales. Inversely, some of the observational techniques could be used to bridge the scale gap between ensemble-averaging mesoscale modeling and case study-based microscale modeling. But also this remains an open issue in complex terrain as well as it has been so long for homogeneous terrain or urban areas (see [40] and further references therein).

Crowdsourcing is also an alternative to explore how to obtain horizontally highly-resolving data [172]. The long list of experiments given in the introduction of this paper shows that the issue of covering atmospheric conditions in complex terrain has already been recognized several decades ago. The fact that a perfect solution has not yet been found, points to the intrinsic difficulties of this issue.

Although the development of measurement instruments and strategies is presently ongoing at rather high speed, a solution for a full coverage of transport and exchange processes in the boundary layer over mountainous terrain does not seem to be very near. Therefore, it can be expected that 
new measurement techniques and data evaluation algorithms will continue to evolve in the future, which — hopefully — bring us a bit closer to a solution. The important role of complex terrain for exchange between the surface/near surface and the upper atmosphere in the climate system justifies every effort in this direction.

Author Contributions: Writing—Original draft, S.E., N.K., B.A., E.P., A.P. and W.J.; Writing—Review \& editing, S.E. Funding: This review received no external funding.

Acknowledgments: We thank the reviewer Dino Zardi from the University of Trento in Italy for supplying us with further references which were highly welcome.

Conflicts of Interest: The authors declare no conflict of interest.

\section{References}

1. Kirshbaum, D.; Adler, B.; Kalthoff, N.; Barthlott, C.; Serafin, S. Moist orographic convection: Physical mechanisms and links to surface-exchange processes. Atmosphere 2018, 9, 80. [CrossRef]

2. Smith, R.B. The influence of mountains on the atmosphere. Adv. Geophys. 1979, 21, 87-230.

3. Blumen, W. (Ed.) Atmospheric Processes over Complex; American Meteorological Society: Boston, MA, USA, 1990; ISBN 978-1-935704-25-6.

4. Reiter, E.R. Where we are and where we are going in mountain meteorology. Bull. Am. Meteorol. Soc. 1982, 63, 1114-1122. [CrossRef]

5. Kuettner, J.P. The Aim and Conduct of ALPEX. Scientific Results of the Alpine Experiment; GARP Publications Series No. 27, 1986, WMO/TD 108; World Meteorological Organization: Geneva, Switzerland, 1986; pp. 3-14.

6. Bougeault, P.; Benech, B.; Bessemoulin, P.; Carissimo, B.; Clar, A.J.; Pelon, J.; Petitdidier, M.; Richard, E. PYREX: A summary of findings. Bull. Am. Meteorol. Soc. 1997, 78, 637-650. [CrossRef]

7. Wratt, D.S.; Ridley, R.N.; Sinclair, M.R.; Larsen, H.; Thompson, S.M.; Henderson, R.; Austin, G.L.; Bradley, S.G.; Auer, A.; Sturman, A.P.; et al. The New Zealand Southern Alps Experiment. Bull. Am. Meteorol. Soc. 1996, 77, 683-692. [CrossRef]

8. Bougeault, P.; Binder, P.; Buzzi, A.; Dirks, R.; Houze, R.; Kuettner, J.; Smith, R.B.; Steinacker, R.; Volkert, H. The MAP special observing period. Bull. Am. Meteorol. Soc. 2001, 82, 433-462. [CrossRef]

9. Rotach, M.W.; Zardi, D. On the boundary-layer structure over highly complex terrain: Key findings from MAP. Q. J. R. Meteorol. Soc. 2007, 133, 937-948. [CrossRef]

10. Fiedler, F.; Borrell, P. TRACT: Transport of air pollutants over complex terrain. In Exchange and Transport of Air Pollutants over Complex Terrain and the Sea; Springer-Verlag: Berli/Heidelberg, Germany; New York, NY, USA, 2000; pp. 223-268, ISBN 3-540-67438-1.

11. Chow, F.K.; Schär, C.; Ban, N.; Lundquist, K.A.; Schlemmer, L.; Shi, X. Crossing multiple gray zones in the transition from mesoscale to microscale simulation over complex terrain. Atmosphere 2018. in preparation.

12. Emeis, S. Measurement Methods in Atmospheric Sciences. In Situ and Remote; Borntraeger: Stuttgart, Germany, 2010.

13. Lugauer, M.; Winkler, P. Thermal circulation in South Bavaria-Climatology and synoptic aspects. Meteorol. Z. 2005, 14, 15-30. [CrossRef]

14. De Wekker, S.F.J.; Giovannini, L.; Gutmann, E.; Knievel, J.C.; Kossmann, M.; Zardi, D. Meteorological applications benefiting from an improved understanding of atmospheric exchange processes over mountains. Atmosphere 2018, 9, 371. [CrossRef]

15. Serafin, S.; Adler, B.; Cuxart, J.; De Wekker, S.F.J; Gohm, A.; Grisogono, B.; Kalthoff, N.; Kirshbaum, D.J.; Rotach, M.W.; Schmidli, J.; et al. Exchange processes in the atmospheric boundary layer over mountainous terrain. Atmosphere 2018, 9, 102. [CrossRef]

16. Stull, R. An Introduction to Boundary Layer Meteorology; Kluwer Academic Publishers: Dordrecht, The Netherlands, 1988.

17. Beljaars, A.C.M.; Holtslag, A.A.M. Flux Parameterization over Land Surfaces for Atmospheric models. J. Appl. Meteorol. 1991, 30, 327-341. [CrossRef]

18. Lehner, M.; Rotach, M.W. Current challenges in understanding and predicting transport and exchange in the atmosphere over mountainous terrain. Atmosphere 2018, 9, 276. [CrossRef] 
19. Fernando, H.J.S.; Pardyjak, E.R.; Di Sabatino, S.; Chow, F.K.; De Wekker, S.F.J.; Hoch, S.W.; Steenburgh, W.J. The MATERHORN: Unraveling the intricacies of mountain weather. Bull. Am. Meteorol. Soc. 2015, 96, 1945-1967. [CrossRef]

20. Cuxart, J.; Conangla, L.; Martínez-Villagrasa, D.; Wrenger, B.; Miró, J.R.; Simó, G.; Jiménez, M.A. Evolution of the temperature profile during the life-cycle of a valley-confined cold pool in the Pyrenees. In Proceedings of the ICAM 2017, Reykjavik, Island, 18-23 June 2017.

21. Paci, A.; Cuxart, J.; Bech, J.; Soler, M.R.; Miró, J.R. The Cerdanya-2017 field experiment: An overview of the campaign and a few preliminary results. In Proceedings of the ICAM 2017, Reykjavik, Island, 18-23 June 2017.

22. Zacharias, S.; Bogena, H.; Samaniego, L.; Mauder, M.; Fuß, R.; Pütz, T.; Frenzel, M.; Schwank, M.; Baessler, C.; Butterbach-Bahl, K.; et al. A Network of Terrestrial Environmental Observatories in Germany. Vadose Zone J. 2011, 10, 955-973. [CrossRef]

23. Whiteman, C.D.; Muschinski, A.; Zhong, S.; Fritts, D.; Hoch, S.W.; Hahnenberger, M.; Yao, W.; Hohreiter, V.; Behn, M.; Cheon, Y.; et al. Metcrax 2006. Bull. Am. Meteorol. Soc. 2008, 89, 1665-1680. [CrossRef]

24. Lehner, M.; Whiteman, D.; Hoch, S.W.; Crosman, E.; Jeglum, M.; Cherukuru, N.; Calhoun, R.; Adler, B.; Kalthoff, N.; Rotunno, R.; et al. The METCRAX II field experiment-A study of downslope windstorm-type flows in Arizona's Meteor Crater. Bull. Am. Meteorol. Soc. 2016, 97, 217-235. [CrossRef]

25. Wolf, B.; Chwala, C.; Fersch, B.; Garvelmann, J.; Junkermann, W.; Zeeman, M.J.; Angerer, A.; Adler, B.; Beck, C.; Brosy, C.; et al. The ScaleX campaign: Scale-crossing land-surface and boundary layer processes in the TERENO-preAlpine observatory. Bull. Am. Meteorol. Soc. 2017, 98, 1217-1234. [CrossRef]

26. Mauder, M.; Desjardins, R.L.; Pattey, E.; Worth, D. An Attempt to Close the Daytime Surface Energy Balance Using Spatially-Averaged Flux Measurements. Bound. Layer Meteorol. 2010, 136, 175-191. [CrossRef]

27. Grubišić, V.; Doyle, D.D.; Kuettner, J.; Mobbs, S.; Smith, R.B.; Whiteman, C.D.; Dirks, R.; Czyzyk, S.; Cohn, S.A.; Vosper, S.; et al. The Terrain-Induced Rotor Experiment: A field campaign overview including observational highlights. Bull. Am. Meteorol. Soc. 2008, 89, 1513-1533. [CrossRef]

28. Wulfmeyer, V.; Behrendt, A.; Kottmeier, C.; Corsmeier, U.; Barthlott, C.; Craig, G.C.; Hagen, M.; Althausen, D.; Aoshima, F.; Arpagaus, M.; et al. The Convective and Orographically-induced Precipitation Study (COPS): The scientific strategy, the field phase, and research highlights. Q. J. R. Meteorol. Soc. 2011, 137, 3-30. [CrossRef]

29. Ducrocq, V.; Braud, I.; Davolio, S.; Ferretti, R.; Flamant, C.; Jansa, A.; Kalthoff, N.; Richard, E.; Taupier-Letage, I.; Ayral, P.A.; et al. HyMeX-SOP1, the field campaign dedicated to heavy precipitation and flash flooding in the northwestern Mediterranean. Bull. Am. Meteorol. Soc. 2014, 95, 1083-1100. [CrossRef]

30. The Passy-2015 Field Experiment: Atmospheric Dynamics and Air Quality in the Arve River Valley. Available online: http:/ / lodel.irevues.inist.fr/pollution-atmospherique/index.php?id=5903\&format=print (accessed on 9 July 2018).

31. Staquet, C.; Duarte, J.Q.; Todzo, S.; Peinke, I.; Arduini, G.; Chemel, C.; Troude, F. On the relationship between atmospheric dynamics and PM10 concentration in the Arve Valley around Passy. In Proceedings of the ICAM 2017, Reykjavik, Island, 18-23 June 2017.

32. Rotach, M.W.; Stiperski, I.; Fuhrer, O.; Goger, B.; Gohm, A.; Obleitner, F.; Rau, G.; Sfyri, E.; Vergeiner, J. Investigating exchange processes over complex topography: The Innsbruck box (i-Box). Bull. Am. Meteorol. Soc. 2017, 98, 787-805. [CrossRef]

33. Watanabe, F.; Uchida, T. Micro-Siting of Wind Turbine in Complex Terrain: Simplified Fatigue Life Prediction of Main Bearing in Direct Drive Wind Turbines. Wind Eng. 2015, 39, 349-368. [CrossRef]

34. Lange, J.; Mann, J.; Berg, J.; Parvu, D.; Kilpatrick, R.; Costache, A.; Chowdhury, J.; Siddiqui, K.; Hangan, H. For wind turbines in complex terrain, the devil is in the detail. Environ. Res. Lett. 2017, 12, 094020. [CrossRef]

35. Rendón, A.M.; Salazar, J.F.; Palacio, C.A.; Wirth, V.; Brötz, B. Effects of Urbanization on the Temperature Inversion Breakup in a Mountain Valley with Implications for Air Quality. J. Appl. Meteorol. Climatol. 2014, 53, 840-858. [CrossRef]

36. Lareau, N.P.; Crosman, E.; Whiteman, C.D.; Horel, J.D.; Hoch, S.W.; Brown, W.O.; Horst, T.W. The persistent cold-air pool study. Bull. Am. Meteorol. Soc. 2013, 94, 51-63. [CrossRef]

37. Giovannini, L.; Zardi, D.; de Franceschi, M. Analysis of the Urban Thermal Fingerprint of the City of Trento in the Alps. J. Appl. Meteorol. Climatol. 2011, 50, 1145-1162. [CrossRef] 
38. Heimann, D.; de Franceschi, M.; Emeis, S.; Lercher, P.; Seibert, P. (Eds.) Air Pollution, Traffic Noise and Related Health Effects in the Alpine Space-A Guide for Authorities and Consulters; Università degli Studi di Trento, Dipartimento di Ingegneria Civile e Ambientale: Trento, Italy, 2007.

39. De Franceschi, M.; Zardi, D. Study of wintertime high pollution episodes during the Brenner-South ALPNAP measurement campaign. Meteorol. Atmos. Phys. 2009, 103, 237-250. [CrossRef]

40. Emeis, S. Observational techniques to assist the coupling of CWE/CFD models and meso-scale meteorological models. J. Wind Eng. Ind. Aerodyn. 2015, 144, 24-30. [CrossRef]

41. Baumgaertner, A.J.G.; Jöckel, P.; Kerkweg, A.; Sander, R.; Tost, H. Implementation of the Community Earth System Model (CESM) version 1.2.1 as a new base model into version 2.50 of the MESSy framework. Geosci. Model Dev. 2016, 9, 125-135. [CrossRef]

42. Hacker, J.M.; Chen, D.; Bai, M.; Ewenz, C.; Junkermann, W.; Lieff, W.; McManus, B.; Neininger, B.; Sun, J.; Coates, T.; et al. Using airborne technology to quantify and apportion emissions of $\mathrm{CH}_{4}, \mathrm{~N}_{2} \mathrm{O}$ and $\mathrm{NH}_{3}$ from feedlots. Anim. Prod. Sci. 2016, 56, 190-203. [CrossRef]

43. Vosper, S.B.; Ross, A.N.; Renfrew, I.A.; Sheridan, P.F.; Elvidge, A.D.; Grubisić, V. Current challenges in orographic flow dynamics: Turbulent exchange due to gravity-wave processes. Atmosphere 2018, 9, 361. [CrossRef]

44. Adler, B.; Kalthoff, N. Multiple-scale transport processes observed in the boundary layer over a mountainous island. Bound.-Layer Meteorol. 2014, 153, 515-537. [CrossRef]

45. Adler, B.; Kalthoff, N. The impact of upstream flow on the atmospheric boundary layer in a valley on a mountainous island. Bound.-Layer Meteorol. 2016, 158, 429-452. [CrossRef]

46. McGowan, H.A.; Sturman, A.P. Atmospheric boundary layer development over a narrow coastal plain during onshore flow. Meteorol. Z. 2005, 14, 3-14. [CrossRef]

47. Emeis, S.; Jahn, C.; Münkel, C.; Münsterer, C.; Schäfer, K. Multiple atmospheric layering and mixing-layer height in the Inn valley observed by remote sensing. Meteorol. Z. 2007, 16, 415-424. [CrossRef]

48. Sprenger, M.; Schmidli, J.; Egloff, L. The Laseyer wind storm-Case studies and a climatology. Meteorol. Z. 2017, 27, 15-32. [CrossRef]

49. Sabatier, T.; Paci, A.; Canut, G.; Largeron, Y.; Dabas, A.; Donier, J.M.; Douffet, T. Wintertime local wind dynamics from scanning doppler lidar and air quality in the Arve River valley. Atmosphere 2018, 9, 118. [CrossRef]

50. Furger, F.; Dommen, J.; Graber, W.K.; Poggio, L.; Prévôt, A.; Emeis, S.; Trickl, T.; Grell, G.; Neininger, B.; Wotawa, G. The VOTALP Mesolcina Valley Campaign 1996-Concept, Background and some Highlights. Atmos. Environ. 2000, 34, 1395-1412. [CrossRef]

51. Khodayar, S.; Kalthoff, N.; Fiebig-Wittmaack, M.; Kohler, M. Evolution of the atmospheric boundary-layer structure of an arid Andes Valley. Meteorol. Atmos. Phys. 2008, 99, 181-198. [CrossRef]

52. Bischoff-Gauß, I.; Kalthoff, N.; Khodayar, S.; Fiebig-Wittmaack, M.; Montecinos, S. Model simulations of the boundary-layer evolution over an arid Andes valley. Bound.-Layer Meteorol. 2008, 128, 357-379. [CrossRef]

53. Dosio, A.; Emeis, S.; Graziani, G.; Junkermann, W.; Levy, A. Assessing the meteorological conditions in a deep Alpine valley system by a measuring campaign and simulation with two models during a summer smog episode. Atmos. Environ. 2001, 35, 5441-5454. [CrossRef]

54. Turnipseed, A.A.; Anderson, D.E.; Blanken, P.D.; Baugh, W.M.; Monson, R.K. Airflows and turbulent flux measurements in mountainous terrain: Part 1. Canopy and local effects. Agric. For. Meteorol. 2003, 119, 1-21. [CrossRef]

55. Schmid, H.P. Source areas for scalars and scalar fluxes. Bound.-Layer Meteorol. 1994, 67, 293-318. [CrossRef]

56. Kljun, N.; Calanca, P.; Rotach, M.W.; Schmid, H.P. A simple two-dimensional parameterisation for flux footprint prediction (FFP). Geosci. Model Dev. 2015, 8, 3695-3713. [CrossRef]

57. Steinfeld, G.; Raasch, S.; Markkanen, T. Footprints in homogeneously and heterogeneously driven boundary layers derived from a Lagrangian stochastic particle model embedded into large-eddy simulation. Bound.-Layer Meteorol. 2008, 129, 225-248. [CrossRef]

58. Pauscher, L.; Callies, D.; Klaas, T.; Foken, T. Wind observations from a forested hill: Relating turbulence statistics to surface characteristics in hilly and patchy terrain. Meteorol. Z. 2018, 27, 43-57. [CrossRef]

59. WMO. Guide to Meteorological Instruments and Methods of Observation; World Meteorological Organization: Geneva, Switzerland, 2008. 
60. Banta, R.M.; Shun, C.M.; Law, D.C.; Brown, W.; Reinking, R.F.; Hardesty, R.M.; Senff, C.J.; Brewer, W.A.; Post, M.J.; Darby, L.S. Observational techniques: Sampling the mountain atmosphere. In Mountain Weather Research and Forecasting: Recent Progress and Current Challenges; Chow, F.K., De Wekker, S.F., Snyder, B.J., Eds.; Springer: Dordrecht, The Netherlands, 2013; pp. 409-530.

61. Christen, A.; Van Gorsel, E.; Vogt, R.; Andretta, M.; Rotach, M.W. Ultrasonic anemometer instrumentation at steep slopes-wind tunnel study-field intercomparison-measurements. MAP Meet. Sch. 2001, 15, 206-209.

62. Rotach, M.W.; Andretta, M.; Calanca, P.; Weigel, P.; Weiss, A. Boundary layer characteristics and turbulent exchange mechanisms in highly complex terrain. Acta Geophys. 2008, 56, 194-219. [CrossRef]

63. Hoch, S.W.; Whiteman, C.D. Topographic Effects on the Surface Radiation Balance in and around Arizona's Meteor Crater. J. Appl. Meteorol. Climatol. 2010, 49, 1114-1128. [CrossRef]

64. Emeis, S. Surface Pressure Distribution and Pressure Drag on Mountains. Meteorol. Atmos. Phys. 1990, 43, 173-185. [CrossRef]

65. Emeis, S. Pressure Drag of Obstacles in the Atmospheric Boundary Layer. J. Appl. Meteorol. 1990, 29, 461-476. [CrossRef]

66. Bessemoulin, P.; Bougeault, P.; Genoves, A.; Clar, A.J.; Puech, D. Mountain pressure drag during PYREX. Contrib. Atmos. Phys. 1993, 66, 305-325.

67. Laiti, L.; Giovannini, L.; Zardi, D.; Belluardo, G.; Moser, D. Estimating Hourly Beam and Diffuse Solar Radiation in an Alpine Valley: A Critical Assessment of Decomposition Models. Atmosphere 2018, 9, 117. [CrossRef]

68. Castelli, M.; Stöckli, R.; Zardi, D.; Tetzlaff, A.; Wagner, J.E.; Belluardo, G.; Zebisch, M.; Petitta, M. The HelioMont method for assessing solar irradiance over complex terrain: Validation and improvements. Remote Sens. Environ. 2014, 152, 603-613. [CrossRef]

69. Voogt, J.A.; Grimmond, C.S.B. Modeling surface sensible heat flux using surface radiative temperatures in a simple urban area. J. Appl. Meteorol. 2000, 39, 1679-1699. [CrossRef]

70. Christen, A.; Meier, F.; Scherer, D. High-frequency fluctuations of surface temperatures in an urban environment. Theory Appl. Climatol. 2012, 108, 301-324. [CrossRef]

71. Garai, A.; Pardyjak, E.R.; Steeneveld, G.J.; Kleissl, J. Surface Temperature and Surface-Layer Turbulence in a Convective Boundary Layer. Bound.-Layer Meteorol. 2013, 148, 51-72. [CrossRef]

72. Dakin, J.; Pratt, D.; Bibby, G.; Ross, J. Distributed optical fibre Raman temperature sensor using a semiconductor light source and detector. Electron Lett. 1985, 21, 569-570. [CrossRef]

73. Tyler, S.W.; Selker, J.S.; Hausner, M.B.; Hatch, C.E.; Torgersen, T.; Thodal, C.E.; Schladow, S.G. Environmental temperature sensing using Raman spectra DTS fiber-optic methods. Water Resour. Res. 2009, 45, W00D23. [CrossRef]

74. Mahrt, L.; Thomas, C.K. Surface Stress with Non-stationary Weak Winds and Stable Stratification. Bound.-Layer Meteorol. 2016, 159, 3-21. [CrossRef]

75. Sayde, C.; Thomas, C.K.; Wagner, J.; Selker, J. High-resolution wind speed measurements using actively heated fiber optics. Geophys. Res. Lett. 2015, 42, 10064-10073. [CrossRef]

76. Román-Cascón, C.; Yagüe, C.; Mahrt, L.; Sastre, M.; Steeneveld, G.J.; Pardyjak, E. Interactions among drainage flows, gravity waves and turbulence: A BLLAST case study. Atmos. Chem. Phys. 2015, 15, 9031-9047. [CrossRef]

77. Adler, B.; Whiteman, C.D.; Hoch, S.W.; Lehner, M.; Kalthoff, N. Warm-Air Intrusions in Arizona's Meteor Crater. J. Appl. Meteorol. Climatol. 2012, 51, 1010-1025. [CrossRef]

78. Giovannini, L.; Laiti, L.; Serafin, S.; Zardi, D. The thermally driven diurnal wind system of the Adige Valley in the Italian Alps. Q. J. R. Meteorol. Soc. 2017, 143, 2389-2402. [CrossRef]

79. Whiteman, C.D. Mountain Meteorology: Fundamentals and Applications; Oxford University Press: Oxford, UK, 2000.

80. Mauder, M.; Foken, T. Impact of post-field data processing on eddy covariance flux estimates and energy balance closure. Meteorol. Z. 2006, 15, 597-609. [CrossRef]

81. Vickers, D.; Mahrt, L. Quality control and flux sampling problems for tower and aircraft data. J. Atmos. Ocean. Technol. 1997, 14, 512-526. [CrossRef]

82. Lee, X.; Massman, W.; Law, B. (Eds.) Handbook of Micrometeorology: A Guide for Surface Flux Measurement and Analysis; Springer Science \& Business Media: Berlin/Heidelberg, Germany, 2006; Volume 29. 
83. Aubinet, M.; Vesala, T.; Papale, D. (Eds.) Eddy Covariance: A Practical Guide to Measurement and Data Analysis; Springer Science \& Business Media: Berlin/Heidelberg, Germany, 2012.

84. Nadeau, D.F.; Pardyjak, E.R.; Higgins, C.W.; Parlange, M.B. Similarity scaling over a steep alpine slope. Bound.-Layer Meteorol. 2016, 147, 401-419. [CrossRef]

85. Stiperski, I.; Rotach, M. On the measurement of turbulence over complex mountainous terrain. Bound.-Layer Meteorol. 2016, 159, 97-121. [CrossRef]

86. McMillen, R.T. An eddy correlation technique with extended applicability to non-simple terrain. Bound.-Layer Meteorol. 1988, 43, 231-245. [CrossRef]

87. Wilczak, J.M.; Oncley, S.P.; Stage, S.A. Sonic anemometer tilt correction algorithms. Bound.-Layer Meteorol. 2001, 99, 127-150. [CrossRef]

88. Yuan, R.; Kang, M.; Park, S.-B.; Hong, J.; Lee, D.; Kim, J. Expansion of the planar-fit method to estimate flux over complex terrain. Meteorol. Atmos. Phys. 2011, 110, 123-133. [CrossRef]

89. Ross, A.N.; Grant, E.R. A new continuous planar fit method for calculating fluxes in complex, forested terrain. Atmos. Sci. Lett. 2015, 16, 445-452. [CrossRef]

90. Oldroyd, H.O.; Pardyjak, E.R.; Huwald, H.; Parlange, M.B. Adapting tilt corrections and the governing flow equations for steep, fully three-dimensional, mountainous terrain. Bound.-Layer Meteorol. 2016, 159, 539-565. [CrossRef]

91. Soltani, M.; Mauder, M.; Laux, P.; Kunstmann, H. Turbulent flux variability and energy balance closure in the TERENO prealpine observatory: A hydrometeorological data analysis. Theory Appl. Climatol. 2018, 133, 937-956. [CrossRef]

92. Emeis, S. Surface-Based Remote Sensing of the Atmospheric Boundary Layer; Springer: Berlin/Heidelberg, Germany, 2011.

93. Rose, T.; Crewell, S.; Löhnert, U.; Simmer, C. A network suitable microwave radiometer for operational monitoring of the cloudy atmosphere. Atmos. Res. 2005, 75, 183-200. [CrossRef]

94. Löhnert, U.; Turner, D.D.; Crewell, S. Ground-based temperature and humidity profiling using spectral infrared and microwave observations. Part 1. Retrieval performance in clear sky conditions. J. Appl. Meteorol. Clim. 2009, 5, 1017-1032. [CrossRef]

95. Crewell, S.; Löhnert, U. Accuracy of boundary layer temperature profiles retrieved with multifrequency multiangle microwave radiometry. IEEE Trans. Geosci. Remote Sens. 2007, 45, 2195-2201. [CrossRef]

96. Martinet, P.; Cimini, D.; De Angelis, F.; Canut, G.; Unger, V.; Guillot, R.; Tzanos, D.; Paci, A. Combining ground-based microwave radiometer and the AROME convective scale model through 1DVAR retrievals in complex terrain: An Alpine valley case study. Atmos. Meas. Tech. 2017, 10, 3385-3402. [CrossRef]

97. Massaro, G.; Stiperski, I.; Pospichal, B.; Rotach, M. Accuracy of retrieving temperature and humidity profiles by ground-based microwave radiometry in truly complex terrain. Atmos. Meas. Tech. 2015, 8, 3355-3367. [CrossRef]

98. Bevis, M.; Businger, S.; Herring, T.A.; Rocken, C.; Anthes, R.A.; Ware, R.H. GPS meteorology: Remote sensing of atmospheric water vapor using the Global Positioning System. J. Geophys. Res. Atmos. 1992, 97, 15787-15801. [CrossRef]

99. Adler, B.; Kalthoff, N.; Kohler, M.; Handwerker, J.; Wieser, A.; Corsmeier, U.; Kottmeier, C.; Lambert, D.; Bock, $\mathrm{O}$. The variability of water vapour and pre-convective conditions over the mountainous island of Corsica. Q. J. R. Meteorol. Soc. 2016, 142, 335-346. [CrossRef]

100. Poggio, L.P.; Furger, M.; Prevot, A.S.H.; Graber, W.K.; Andreas, E.L. Scintillometer wind measurements over complex terrain. J. Atmos. Ocean. Technol. 2000, 17, 17-26. [CrossRef]

101. Furger, M.; Drobinski, P.; Prévôt, A.H.; Weber, R.O.; Graber, W.K.; Neininger, B. Comparison of horizontal and vertical scintillometer crosswinds during strong foehn with lidar and aircraft measurements. J. Atmos. Ocean. Technol. 2001, 18, 1975-1988. [CrossRef]

102. Meijninger, W.; Beyrich, F.; Lüdi, A.; Kohsiek, W.; De Bruin, H. Scintillometer-based turbulent fluxes of sensible and latent heat over a heterogeneous land surface-A contribution to LITFASS-2003. Bound.-Layer Meteorol. 2006, 121, 89-110. [CrossRef]

103. Ward, H.C. Scintillometry in urban and complex environments: A review. Meas. Sci. Technol. 2017, $28,064005$. [CrossRef]

104. Ward, H.C.; Evans, J.G.; Grimmond, C.S.B.; Bradford, J. Infrared and millimetre-wave scintillometry in the suburban environment. Part 1: Structure parameters. Atmos. Meas. Tech. 2015, 8, 1385-1405. [CrossRef] 
105. Wulfmeyer, V.; Hardesty, R.M.; Turner, D.D.; Behrendt, A.; Cadeddu, M.P.; Di Girolamo, P.; Schlüssel, P.; Van Baelen, J.; Zus, F. A review of the remote sensing of lower tropospheric thermodynamic profiles and its indispensable role for the understanding and the simulation of water and energy cycles. Rev. Geophys. 2015, 53, 819-895. [CrossRef]

106. Froidevaux, M.; Higgins, C.W.; Simeonov, V.; Ristori, P.; Pardyjak, E.R.; Serikov, I. A Raman lidar to measure water vapor in the atmospheric boundary layer. Adv. Water Resour. 2013, 51, 345-356. [CrossRef]

107. Bradley, S.; Strehz, A.; Emeis, S. Remote sensing winds in complex terrain-A review. Meteorol. Z. 2015, 24, 547-555. [CrossRef]

108. Bradley, S.; Perrott, Y.; Behrens, P.; Oldroyd, A. Corrections for wind-speed errors from sodar and lidar in complex terrain. Bound.-Layer Meteorol. 2012, 143, 37-48. [CrossRef]

109. Calhoun, R.; Heap, R.; Princevac, M.; Newsom, R.; Fernando, H.; Ligon, D. Virtual towers using coherent Doppler lidar during the joint urban 2003 dispersion experiment. J. Appl. Meteorol. Climatol. 2006, 45, 1116-1126. [CrossRef]

110. Lane, S.E.; Barlow, J.F.; Wood, C.R. An assessment of a three- beam Doppler lidar wind profiling method for use in urban areas. J. Wind Eng. Ind. Aerodyn. 2013, 119, 53-59. [CrossRef]

111. Röhner, L.; Träumner, K. Aspects of convective boundary layer turbulence measured by a dual-Doppler lidar system. J. Atmos. Ocean. Technol. 2013, 30, 2132-2142. [CrossRef]

112. Newsom, R.; Calhoun, R.; Ligon, D.; Allwine, J. Linearly organized turbulence structures observed over asuburban area by dual-Doppler lidar. Bound.-Layer Meteorol. 2008, 127, 111. [CrossRef]

113. Hill, M.; Calhoun, R.; Fernando, H.; Wieser, A.; Dörnbrack, A.; Weissmann, M.; Mayr, G.; Newsom, R. Coplanar Doppler lidar retrieval of rotors from T-REX. J. Atmos. Sci. 2010, 67, 713-729. [CrossRef]

114. Träumner, K.; Damian, T.; Stawiarski, C.; Wieser, A. Turbulent structures and coherence in the atmospheric surface layer. Bound.-Layer Meteorol. 2015, 154, 1-25. [CrossRef]

115. Vasiljević, N. A Time-Space Synchronization of Coherent Doppler Scanning Lidars for 3D Measurements of Wind Fields. Ph.D. Thesis, Technical University of Denmark, Roskilde, Denmark, 2014.

116. Mikkelsen, T.; Sjöholm, M.; Angelou, N.; Mann, J. 3D Wind Scanner Lidar Measurements of Wind and Turbulence around Wind Turbines, Buildings and Bridges; IOP Publishing: Bristol, UK, 2017; Volume 276, p. 012004.

117. Stawiarski, C.; Träumner, K.; Kottmeier, C.; Knigge, C.; Raasch, S. Assessment of surface layer coherent structure detection in Dual-Doppler lidar data based on virtual measurements. Bound.-Layer Meteorol. 2015, 156, 371-393. [CrossRef]

118. Iungo, G.V.; Wu, Y.T.; Porté-Agel, F. Field measurements of wind turbine wakes with lidars. J. Atmos. Ocean. Technol. 2013, 30, 274-287. [CrossRef]

119. Trabucchi, D.; Trujillo, J.J.; Schneemann, J.; Bitter, M.; Kühn, M. Application of staring lidars to study the dynamics of wind turbine wakes. Meteorol. Z. 2015, 24, 557-564. [CrossRef]

120. Jakobsen, J.B.; Cheynet, E.; Snæbjörnsson, J.; Mikkelsen, T.; Sjöholm, M.; Angelou, N.; Hansen, P.; Mann, J.; Svardal, B.; Kumer, V.; et al. Application of lidars for assessment of wind conditions on a bridge site. In Proceedings of the 14th International Conference on Wind Engineering, Beijing, China, 1-6 September 2015.

121. Vasiljević, N.; Palma, J.M.; Angelou, N.; Matos, J.C.; Menke, R.; Lea, G.; Mann, J.; Courtney, M.; Ribeiro, L.F.; Gomes, V.M. Perdigão 2015: Methodology for atmospheric multi-Doppler lidar experiments. Atmos. Meas. Tech. 2017, 10, 3463-3483. [CrossRef]

122. Stawiarski, C.; Träumner, K.; Knigge, C.; Calhoun, R. Scopes and challenges of Dual-Doppler Lidar wind measurements-An error analysis. J. Atmos. Ocean. Technol. 2013, 30, 2044-2061. [CrossRef]

123. Whiteman, C.D.; Lehner, M.; Hoch, S.W.; Adler, B.; Kalthoff, N.; Haiden, T. Katabatically driven cold air intrusions into a basin atmosphere. J. Appl. Meteorol. Climatol. 2018, 57, 435-455. [CrossRef]

124. Whiteman, C.D.; Lehner, M.; Hoch, S.W.; Adler, B.; Kalthoff, N.; Vogt, R.; Feigenwinter, I.; Haiden, T.; Hills, M.O. The nocturnal evolution of atmospheric structure in a basin as a larger-scale katabatic flow is lifted over its rim. J. Appl. Meteorol. Climatol. 2018, 57, 969-989. [CrossRef]

125. Groenemeijer, P.; Barthlott, C.; Behrendt, A.; Corsmeier, U.; Handwerker, J.; Kohler, M.; Mahlke, H.; Pal, S.; Radlach, M.; Trentmann, J.; et al. Observations of kinematics and thermodynamic structure surrounding a convective storm cluster over a low mountain range. Bull. Am. Meteorol. Soc. 2009, 137, 585-602. [CrossRef]

126. Legain, D.; Bousquet, O.; Douffet, T.; Tzanos, D.; Moulin, E.; Barrie, J.; Renard, J.B. High-frequency boundary layer profiling with reusable radiosondes. Atmos. Meas. Tech. 2013, 6, 2195-2205. [CrossRef] 
127. Lothon, M.; Lohou, F.; Pino, D.; Couvreux, F.; Pardyjak, E.R.; Reuder, J.; Augustin, P. The BLLAST field experiment: Boundary-layer late afternoon and sunset turbulence. Atmos. Chem. Phys. 2014, 14, 10931-10960. [CrossRef]

128. Kalthoff, N.; Lohou, F.; Brooks, B.; Jegede, G.; Adler, B.; Babić, K.; Dione, C.; Ajao, A.; Amekudzi, L.K.; Aryee, J.N.A.; et al. An overview of the diurnal cycle of the atmospheric boundary layer during the West African monsoon season: Results from the 2016 observational campaign. Atmos. Chem. Phys. 2018, 18, 2913-2928. [CrossRef]

129. Canut, G.; Couvreux, F.; Lothon, M.; Legain, D.; Piguet, B.; Lampert, A.; Maurel, W.; Moulin, E. Turbulence fluxes and variances measured with a sonic anemometer mounted on a tethered balloon. Atmos. Meas. Tech. 2016, 9, 4375-4386. [CrossRef]

130. Lenschow, D.H. Airplane Measurements of Planetary Boundary Layer Structure. J. Appl. Meteorol. Climatol. 1970, 9, 874-884. [CrossRef]

131. Metzger, S.; Junkermann, W.; Butterbach-Bahl, K.; Foken, T. Corrigendum to "Measuring the 3-D wind vector with a weight-shift microlight aircraft" Atmos. Meas. Tech., 4, 1421-1444, 2011. Atmos. Meas. Tech. 2011, 4, 1515-1539. [CrossRef]

132. Fritts, D.C.; Smith, R.B.; Taylor, M.J.; Doyle, J.D.; Eckermann, S.D.; Dörnbrack, A.; Rapp, M.; Williams, B.P.; Pautet, P.; Bossert, K.; et al. The Deep Propagating Gravity Wave Experiment (DEEPWAVE): An Airborne and Ground-Based Exploration of Gravity Wave Propagation and Effects from Their Sources throughout the Lower and Middle Atmosphere. Bull. Am. Meteorol. Soc. 2016, 97, 425-453. [CrossRef]

133. Schröter, I.; Paasche, H.; Doktor, D.; Xu, X.; Dietrich, P.; Wollschläger, U. Estimating Soil Moisture Patterns with Remote Sensing and Terrain Data at the Small Catchment Scale. Vadose Zone J. 2017, 16. [CrossRef]

134. Junkermann, W.; Vogel, B.; Bangert, M. Ultrafine particles over Germany-An aerial survey. Tellus B 2016, 68, 29250. [CrossRef]

135. De Franceschi, M.; Rampanelli, G.; Sguerso, D.; Zardi, D.; Zatelli, P. Development of a measurement platform on a light airplane and analysis of airborne measurements in the atmospheric boundary layer. Ann. Geophys. 2003, 46, 269-283.

136. Junkermann, W. An Ultralight Aircraft as Platform for Research in the Lower Troposphere: System Performance and First Results from Radiation Transfer Studies in Stratiform Aerosol Layers and Broken Cloud Conditions. J. Atmos. Ocean. Technol. 2001, 18, 934-946. [CrossRef]

137. Metzger, S.; Junkermann, W.; Mauder, M.; Butterbach-Bahl, K.; Trancón y Widemann, B.; Neidl, F.; Schäfer, K.; Wieneke, S.; Zheng, X.H.; Schmid, H.P.; et al. Spatial resolution and regionalization of airborne flux measurements using environmental response functions. Biogeosciences 2013, 10, 2193-2217. [CrossRef]

138. Metzger, S.; Junkermann, W.; Mauder, M.; Beyrich, F.; Butterbach-Bahl, K.; Schmid, H.P.; Foken, T. Eddy Covariance flux measurements with a weight-shift microlight aircraft. Atmos. Meas. Tech. 2012, 5, 1699-1717. [CrossRef]

139. Hacker, J. Presentation at the 34th International Symposium for Remote Sensing of the Environment, Sydney, 2011. Available online: http:/ / www.airborneresearch.com.au/ISRSE2011_JMH.pdf (accessed on 18 November 2018).

140. Brosy, C.; Krampf, K.; Zeeman, M.; Wolf, B.; Junkermann, W.; Schäfer, K.; Emeis, S.; Kunstmann, H. Simultaneous multicopter-based air sampling and sensing of meteorological variables. Atmos. Meas. Tech. 2017, 10, 2773-2784. [CrossRef]

141. Laiti, L.; Zardi, D.; de Franceschi, M.; Rampanelli, G. Residual Kriging analysis of airborne measurements: Application to the mapping of Atmospheric Boundary-Layer thermal structures in a mountain valley. Atmos. Sci. Lett. 2013, 14, 79-85. [CrossRef]

142. Reitebuch, O.; Werner, C.; Leike, I.; Delville, P.; Flamant, P.H.; Cress, A.; Engelbart, D. Experimental Validation of Wind Profiling Performed by the Airborne 10- $\mu$ m Heterodyne Doppler Lidar WIND. J. Atmos. Ocean. Technol. 2001, 18, 1331-1344. [CrossRef]

143. King, D.J. Airborne multispectral digital camera and video sensors: A critical review of system designs and applications. Can. J. Remote Sens. 1995, 21, 245-273. [CrossRef]

144. Dare, P. The Use of Small Environmental Research Aircraft (SERAs) for Environmental Remote Sensing. Int. J. Geoinf. 2005, 1, 19-26.

145. Spiess, T.; Bange, J.; Buschmann, M.; Vörsmann, P. First application of the meteorological Mini-UAV 'M2AV'. Meteorol. Z. 2007, 16, 159-169. [CrossRef] [PubMed] 
146. Villa, T.F.; Gonzalez, F.; Miljievic, B.; Ristovski, Z.D.; Morawska, L. An Overview of Small Unmanned Aerial Vehicles for Air Quality Measurements: Present Applications and Future Prospectives. Sensors 2016, 16, 1072. [CrossRef] [PubMed]

147. Martin, S.; Bange, J.; Beyrich, F. Meteorological profiling of the lower troposphere using the research UAV "M2AV Carolo". Atmos. Meas. Tech. 2011, 4, 705-716. [CrossRef]

148. De Boer, G.; Palo, S.; Argrow, B.; LoDolce, G.; Mack, J.; Gao, R.-S.; Telg, H.; Trussel, C.; Fromm, J.; Long, C.N.; et al. The Pilatus unmanned aircraft system for lower atmospheric research. Atmos. Meas. Tech. 2016, 9, 1845-1857. [CrossRef]

149. Altstädter, B.; Platis, A.; Wehner, B.; Scholtz, A.; Wildmann, N.; Hermann, M.; Käthner, R.; Baars, H.; Bange, J.; Lampert, A. ALADINA-An unmanned research aircraft for observing vertical and horizontal distributions of ultrafine particles within the atmospheric boundary layer. Atmos. Meas. Tech. 2015, 8, 1627-1639. [CrossRef]

150. Båserud, L.; Reuder, J.; Jonassen, M.O.; Kral, S.T.; Paskyabi, M.B.; Lothon, M. Proof of concept for turbulence measurements with the RPAS SUMO during the BLLAST campaign. Atmos. Meas. Tech. 2016, 9, 4901-4913. [CrossRef]

151. Alvarado, M.; Gonzalez, F.; Fletcher, A.; Doshi, A. Towards the Development of a Low Cost Airborne Sensing System to Monitor Dust Particles after Blasting at Open-Pit Mine Sites. Sensors 2015, 15, 19667-19687. [CrossRef] [PubMed]

152. Chang, C.-C.; Wang, J.-L.; Chang, C.-Y.; Liang, M.-C. Development of a multicopter-carried whole air sampling apparatus and its applications in environmental studies. Chemosphere 2016, 144, 484-492. [CrossRef] [PubMed]

153. Neumann, P.P.; Bartholomai, M. Real-time wind estimation on a micro unmanned aerial vehicle using its inertial measurement unit. Sens. Actuator A 2015, 235, 300-310. [CrossRef]

154. Palomaki, R.T.; Rose, N.T.; van den Bossche, M.; Sherman, T.J.; De Wekker, S.F.J. Wind Estimation in the Lower Atmosphere Using Multirotor Aircraft. Atmos. Ocean. Technol. 2017, 34, 1183-1191. [CrossRef]

155. Wildmann, N.; Ravi, S.; Bange, J. Towards higher accuracy and better frequency response with standard multi-hole probes in turbulence measurement with remotely piloted aircraft (RPA). Atmos. Meas. Tech. 2014, 7, 1027-1041. [CrossRef]

156. Lawrence, D.A.; Balsley, B.B. High-Resolution Atmospheric Sensing of Multiple Atmospheric Variables Using the DataHawk Small Airborne Measurement System. J. Atmos. Ocean. Technol. 2013, 30, 2352-2366. [CrossRef]

157. Calmer, R.; Roberts, G.C.; Preissler, J.; Sanchez, K.J.; Derrien, S.; O’Dowd, C. Vertical wind velocity measurements using a five-hole probe with remotely piloted aircraft to study aerosol-cloud interactions. Atmos. Meas. Tech. 2018, 11, 2583-2599. [CrossRef]

158. Reymann, C.; Renzaglia, A.; Lamraoui, F.; Bronz, M.; Lacroix, S. Adaptive sampling of cumulus clouds with UAVs. Auton. Robot. J. 2018, 42, 491-512. [CrossRef]

159. Dabas, A. Observing the atmospheric wind from space. CR Geosci. 2010, 342, 370-379. [CrossRef]

160. Gascoin, S.; Hagolle, O.; Huc, M.; Jarlan, L.; Dejoux, J.-F.; Szczypta, C.; Marti, R.; Sánchez, R. A snow cover climatology for the Pyrenees from MODIS snow products. Hydrol. Earth Syst. Sci. 2015, 19, 2337-2351. [CrossRef]

161. Drusch, M.; Del Bello, U.; Carlier, S.; Colin, O.; Fernandez, V.; Gascon, F.; Hoersch, B.; Isola, C.; Laberinti, P.; Martimort, P.; et al. Sentinel-2: ESA's optical high-resolution mission for GMES operational services. Remote Sens. Environ. 2012, 120, 25-36. [CrossRef]

162. Chimani, B.; Steinacker, R.; Häberli, C.; Dorninger, M.; Tschannett, S. Objective mesoscale analyses in complex terrain: Application to foehn cases during MAP. Meteorol. Z. 2006, 15, 117-125. [CrossRef]

163. Steinacker, R.; Ratheiser, M.; Bica, B.; Chimani, B.; Dorninger, M.; Gepp, W.; Lotteraner, C.; Schneider, S.; Tschannett, S. A Mesoscale Data Analysis and Downscaling Method over Complex Terrain. Mon. Weather Rev. 2006, 134, 2758-2771. [CrossRef]

164. Kalthoff, N.; Träumner, K.; Adler, B.; Späth, S.; Behrendt, A.; Wieser, A.; Handwerker, J.; Madonna, F.; Wulfmeyer, V. Dry and moist convection in the boundary layer over the Black Forest-A combined analysis of in situ and remote sensing data. Meteorol. Z. 2013, 22, 445-461. [CrossRef]

165. Balsley, B.B. The CIRES Tethered Lifting System: A survey of the system, past results and future capabilities. Acta Geophys. 2008, 56, 21-57. [CrossRef] 
166. Kiemle, C.; Wirth, M.; Fix, A.; Rahm, S.; Corsmeier, U.; DiGirolamo, P. Latent heat flux measurements over complex terrain by airborne water vapour and wind lidars. Q. J. R. Meteorol. Soc. 2011, 137, 190-203. [CrossRef]

167. Miller, M.A.; Nitschke, K.; Ackerman, T.P.; Ferrell, W.R.; Hickmon, N.; Ivey, M. The ARM mobile facilities. AMS Meteorol. Monogr. 2016, 57. [CrossRef]

168. Gustafson, W.I.; Vogelmann, A.M.; Cheng, X.; Endo, S.; Krishna, B.; Li, Z.; Toto, T.; Xiao, H. Recommendations for Implementation of the LASSO Workflow; DOE/SC-ARM-17-031; U.S. Department of Energy, Office of Scientific and Technical Information: Oak Ridge, TN, USA, 2017.

169. Mikkelsen, T.; Mann, J.; Courtney, M. Windscanner: A full-scale laser facility for wind and turbulence measurements around large wind turbines. In Proceedings of the European Wind Energy Conference, Brussels, Belgium, 31 March-3 April 2008.

170. Newman, J.F.; Bonin, T.A.; Klein, P.M.; Wharton, S.; Newsom, R.K. Testing and validation of multi-lidar scanning strategies for wind energy applications. Wind Energy 2016, 19, 2239-2254. [CrossRef]

171. Roininen, R.; Münkel, C. Results from continuous atmospheric boundary layer humidity profiling with a compact DIAL instrument. In Proceedings of the WMO Technical Conference on Meteorological and Environmental Instruments and Methods of Observation, Madrid, Spain, 27-30 September 2016.

172. Muller, C.L.; Chapman, L.; Johnston, S.; Kidd, C.; Illingworth, S.; Foody, G.; Overeem, A.; Leigh, R.R. Crowdsourcing for climate and atmospheric sciences: Current status and future potential. Int. J. Climatol. 2015, 35, 3185-3203. [CrossRef]

(C) 2018 by the authors. Licensee MDPI, Basel, Switzerland. This article is an open access article distributed under the terms and conditions of the Creative Commons Attribution (CC BY) license (http:/ / creativecommons.org/licenses/by/4.0/). 